\title{
CZLOWIEK A ŚRODOWISKO - CZY W IDEI POSTĘPU \\ ZAWSZE TKWI ZIARNO DESTRUKCJI? W DZIEWIĘĆDZIESIĄTĄ ROCZNICĘ URODZIN JEANA DORSTA (1924-2001)
}

\begin{abstract}
Zbigniew Pietrzak
Zasadnicza idea Jeana Dorsta wyraża się w przekonaniu, że działalność wszystkich cywilizacji, w miarę ich postępu technicznego i rozwoju demograficznego, prędzej czy później, prowadzi do nadmiernej eksploatacji otaczającej przyrody. W konsekwencji powoduje to zubożenie jej zasobów i upadek organizmów państwowych. Jean Dorst postuluje konieczność równowagi między potrzebami ludzi, a możliwościami środowiska wskazując przy tym na rolę nauki, polityki a nawet filozofii w rozwiązaniu tych problemów. Po 15 latach od śmierci tego uczonego można już skonfrontować jego prognozy z rzeczywistym rozwojem cywilizacji i jej wpływu na środowisko naturalne. I zadać pytanie: czy postępowi zawsze musi towarzyszyć destrukcja?
\end{abstract}

Słowa kluczowe: cywilizacja/kultura, postęp, zagrożenia ekologiczne, cywilizacja globalna

Idee rządzą światem i dyktują każdemu jego zachowanie.

Pierwszą narzucającą się uwagą jest to, że żaden $\mathrm{z}$ tych światopoglądów, kształtujących nasze doktryny i sposoby rozumowania, nie mógł nam wpoić poszanowania dla naszego naturalnego kapitału ani nauczyć nas chronić go.

Jean Dorst, Siła życia

Zadziwiające jest to, że przytoczona w motcie konstatacja Jeana Dorsta wcale nie jest tak oczywista. Rzadko kiedy bowiem zwracamy uwage na to, że nasze najbardziej ogólne przekonania religijne, filozoficzne, gospodarcze, prawne decydują o tym, jakie budujemy relacje nie tylko

ZBIGNIEW PIETRZAK, doktor filozofii, asystent w Zakładzie Ontologii i Teorii Poznania na Uniwersytecie Wrocławskim, Wrocław, Polska; adres do korespondencji: ul. Koszarowa 3/20, 51-149 Wrocław. E-Mail: zbigpietrzak@wp.pl 
z innymi ludźmi, ale i z przyrodą. Wydaje się, że to, co wpływa na nasze związki z przyrodą ,jakoś samo w sobie jest naturalne" i nie wymaga refleksji. Co więcej, gdy uzmysławiamy sobie, że jednak otaczający nas świat traktujemy zgodnie $\mathrm{z}$,jakimiś przekonaniami”, to wówczas odkrywamy, że są one ukształtowane przez wiedzę naukową na poziomie najbardziej elementarnej edukacji. Oprócz tego, patrzymy na naturę oczami biologa, fizyka, rzadziej chemika lub matematyka, w niektórych sytuacjach lekarza, a nawet psychologa. Mamy więc, $z$ jednej strony zaledwie rudymentarną wiedzę o naturze, $z$ drugiej zaś wyspecjalizowaną wąską perspektywę poznawczą. Poza tym, dzięki religii przyroda może jawić się jako dar Stwórcy, który - jak każdy dar („podarunek”) istnieje po to, by zaspokajać nasze potrzeby.

Jean Dorst ${ }^{1}$ należał do tych nielicznych przyrodników, którzy nieustannie zwracali uwagę na to, że choć w dzisiejszym świecie filozoficzne idee nie sa przywoływane $\mathrm{w}$ badaniach uczonych, a tym bardziej $\mathrm{w}$ codziennej refleksji, to jednak one właśnie kreują naszą wizję natury i jej status. Co więcej, jeżeli nawet uczeni odwoływali się do nich poszukując źródeł naszych działań względem przyrody, to okazywało się, że były one przez nich często trywializowane i niedoceniane, traktowane jako „nieaktywna” pamiątka po jakiejś archaicznej przeszłości, której dziś przypisuje się nadmierną rolę.

Charakterystycznym rysem ekologii lat sześćdziesiątych i siedemdziesiątych był powszechny ekologiczny pesymizm. Postawa ta sprawiała czasami wrażenie mody na głoszenie katastroficznych wizji ludzkiej cywilizacji, budowanych na lęku przed atomową zagładą i niepohamowaną eksploatacją wyczerpujących się coraz bardziej zasobów naturalnych. Dzisiaj, w drugiej dekadzie dwudziestego pierwszego wieku, wydają się one przesadzone i sprawiają wrażenie pewnej maniery, świadcząc o jakiejś psychozie ogarniającej nawet najbardziej światłe i wykształcone umysły minionego wieku. Być może, ten nadmierny pesymizm był „narzędziem” umożliwiającym zwrócenie uwagi szerokiej społeczności na skutki dewastacji przyrody. Bogatsi o dokonania ostatnich czterdziestu lat, sytuujemy siebie w roli wyrozumiałego i nieco nonszalanckiego egzaminatora, który może stwierdzić, iż nie sprawdziły się najczarniejsze scenariusze, ani w kontekście zbrojnych konfliktów z użyciem broni masowej zagłady, ani w przypadku prognoz o ostatecznym i nieodwracalnym zniszczeniu przyrody.

${ }^{1}$ Bibliografię dzieł J. Dorsta można znaleźć na stronie: http://asbric.pagespersoorange.fr/bibli/e-dorst.html 
Tymczasem, jak sądzę, przynajmniej co do tej drugiej wizji, jej nadejście, być może, zostało tylko „odłożone w czasie”. W niniejszym artykule chciałbym zwrócić uwagę na tę kwestię i zasygnalizować przyczyny, dla których, choć nieustanny proces dewastacji środowiska przyrodniczego nadal trwa i prowadzi do jego zagłady, to nie jest on postrzegany już z taką ostrością jak w czasach Jeana Dorsta i Konrada Lorenza. Obaj ci uczeni, nie oparli się pokusie „apokaliptycznej” wizji przyszłości i obaj krytycznie oceniali funkcjonowanie współczesnego im, zachodniego społeczeństwa. Ocenę i formułowane przez obu przyrodników diagnozy uwiarygodniała ich przyrodnicza wiedza ${ }^{3}$. Poszukując źródeł zagrożeń i kryzysu współczesnej cywilizacji, czy to w skali europejskiej czy globalnej, sądzę, iż można wyróżnić trzy perspektywy (trzy modele) wyartykułowane przez Edmunda Husserla, Konrada Lorenza i Jeana Dorsta. Husserl kładł szczególny nacisk na przyczyny intelektualne, teoretyczne związane ze źle uzewnętrznianą ideą racjonalizmu, przejawiającą się także w nauce i filozofii. Konrad Lorenz widział problemy w kategoriach społeczno-biologicznych, przy czym ewidentnie czynnik społeczny wynikał nie tyle z ludzkiej kondycji biologicznej, ale z określonej organizacji społeczeństwa i mniej lub bardziej świadomego wyboru licznych dróg, którymi mogą kroczyć społeczności. Czy będzie to, na przykład, system technokratyczny czy nie, jest kwestią decyzji, choć często sprawiamy wrażenie, jakbyśmy byli uzależnieni od techniki i tak naprawdę nie mieli już możliwości wyboru ${ }^{4}$. Ostatnią perspektywę rysuje

\footnotetext{
${ }^{2} \mathrm{~W}$ tym miejscu pozwolę sobie zasygnalizować, że nie należę do tych ekologicznie nastawionych ludzi, którzy zagładę przyrody postrzegają jako coś nieuniknionego, a tym bardziej jako coś pożądanego, prowadzącego bowiem w ostateczności do wyeliminowania człowieka. Spotkałem się bowiem z może nieco sarkastycznymi opiniami, że najlepszym „wyjściem” dla planety byłoby wymarcie gatunku Homo sapiens.

${ }^{3}$ Akcentując owe dość krytyczne poglądy Lorenza i Dorsta na kwestie związane z działalnością i funkcjonowaniem dzisiejszej cywilizacji zachodu nie chciałbym, aby ktoś odniósł wrażenie, iż uczeni ci cały swój wysiłek skupili na głoszeniu nadchodzącego „końca świata”. Badając przyrodę, nieustannie zwracali uwage na jej niezwykłą „kruchość”, ale z drugiej strony także na jej żywotność.

Krytyka cywilizacji europejskiej nie jest owocem refleksji tylko dwudziestowiecznych myślicieli. Jej zagorzałym wyrazicielem w czasach nowożytnych był Jean-Jacques Rousseau (1712-1778), który w cywilizacji upatrywał korzeni wszelkiego zła i upadku moralnego. Postulat powrotu do natury narzucał się w tym kontekście w sposób oczywisty - można było ją postrzegać jako alternatywę dla „środowiska kultury”, które stworzył sobie człowiek. Przyroda jako twór Boga, cywilizacja jako twór człowieka, uczucia a intelekt, wolność a zniewolenie konwenansami - oto spolaryzowane otoczenie, oto sprzeczności, którymi targany był ówczesny człowiek cywilizowany.

4 E. Husserl, Kryzys nauk europejskich $i$ fenomenologia transcendentalna, tłum. S. Walczewska, Wydawnictwo Rolewski, Toruń 1999; K. Lorenz, Regres człowieczeństwa,
} 
właśnie Dorst, a jej istotną cechą jest wymiar filozoficzno-ekologiczny. Tę perspektywę staram się omówić w niniejszej pracy.

\section{Człowiek kontra przyroda}

W dziejach człowieka, wszystkie społeczności - zarówno zbierackołowieckie, agrarne jak i dzisiejsze przemysłowe i postindustralne - funkcjonowały i funkcjonują $\mathrm{w}$ ramach różnych, pierwotnie nie artykułowanych, fundamentalnych przeświadczeń (zabobonów) kształtujących relację ze środowiskiem. Niewidoczne, narzucają się one z jakąś wewnętrzną dla ludzkiego rozumu logika, a dopiero gdy zostana explicite wyartykułowane, zaczynamy uświadamiać sobie ich obecność i sprawczą, realną moc. Oczywiście, zawsze możemy pytać o to, jakie mogły być źródła owych przeświadczeń, na jakim etapie naszego filogenetycznego rozwoju się one pojawiły się i jak ewoluowały. Możemy też pytać o to, czy przynależą tylko człowiekowi (wszystko wskazuje, że tak), czy też są pojawiają się w jakiejś rudymentarnej formie u innych gatunków, przynajmniej tych najlepiej rozwiniętych pod względem intelektualnym.

Dorst, analizując te przeświadczenia, przypisywał największe oddziaływanie ideom religijnym i filozoficznym, nie pomijał przy tym idei społecznych, prawnych i gospodarczych (które, nota bene, właśnie dzisiaj odgrywają największą rolę). Nie jest zaskakujące, że poszukując religijnych źródeł dla ludzkich relacji z przyrodą, przywołuje on znany boski „nakaz” z Ksiegi Rodzaju: „Bądźcie płodni i rozmnażajcie się, abyście zaludnili ziemię i uczynili ją sobie poddaną; abyście panowali nad rybami morskimi, nad ptactwem powietrznym i nad wszystkimi zwierzętami pełzającymi po ziemi"5. Czy z tego przyzwolenia na eksploatacje przyrody wynika przyzwolenie na jej dewastację? Oczywiście nie, i sądzę, że także Dorst nie twierdziłby, że Bóg „,zachęca” do niszczenia, nieodwracalnego w skutkach, swojego dzieła. Jednakże owe boskie wezwanie, ostatecznie może doprowadzić do zagłady środowiska w wyniku niepohamowanego, zachłannego czerpania z jego zasobów. Antropocentrycznie nakierowana religia pozostawiała dużą swobodę $\mathrm{w}$ podejściu do przyrody - zarówno nieożywionej, jak i ożywionej, uzależniając jej los, dosłownie, od kaprysu człowieka. Ten biblijny obraz dopełnia się później - jak zauważa Dorst - w religii protestanckiej ${ }^{6}$. Charakterystyczna

tłum. A. D. Tauszyńska, PIW, Warszawa 1986. Por. także J. Gray, Stomiane psy. Myśli o ludziach i innych zwierzętach, tłum. C. Cieśliński, Książka i Wiedza, Warszawa 2003.

${ }^{5}$ J. Dorst, Sita.., s. 80; Ks. Rodz., I, 28-29.

${ }^{6}$ Tamże, s. 84 . 
dla protestantyzmu apoteoza pracy będącej błogosławieństwem, a nie karą, przynoszącej człowiekowi dobrobyt, sytuuje go tym samym niejako na zewnątrz przyrody - ona sama zaś służy mu tylko jako przedmiot i środek pracy. Człowiek nie jest elementem natury, zależnym od jej „kondycji”, jest „spoza niej” - ontologicznie, jako byt „stworzony na obraz i podobieństwo Boga" i epistemologicznie, jako poznający podmiot, jedyny, który może dążyć i osiagnąć prawdę. Zarówno judaizm, jak i chrześcijaństwo, choć traktowały przyrodę jako dzieło Boże, doprowadziły do jej desakralizacji i, w przeciwieństwie do innych religii, ustanowiły człowieka w roli pana dążącego do uniezależnienia się od środowiska.

W tym „przedsięwzięciu” pomogły Europejczykom szczególnie idee (postulaty, wezwania) formułowane przez filozofów ${ }^{7}$. Można powiedzieć, że nowożytne, a więc i w dużej części współczesne relacje człowieka ze środowiskiem są wyłącznie efektem europejskiej filozofii. Dorst poszukiwał korzeni naszego wyjątkowego stosunku do przyrody już w starożytności; przejęliśmy w spadku po Grekach i Rzymianach także ten aspekt ich kultury. Niezależnie od tego, że można było naturę postrzegać zgodnie z Arystotelesową ideą hylozoizmu, to za Cyceronem, wedle Dorsta, człowiek zmuszony był do budowania sobie własnego środowiska przyrodniczego ${ }^{8}$. To, co oferowała natura, wymagało przekształcenia, przystosowania do potrzeb, ale i także do możliwości absorbowania jej zasobów. Człowiek nie mógł w pełni korzystać z jej „darów”, dostępnych w „surowym” stanie. Rudy metali, dzika zwierzyna i dzika roślinność wymagały przetworzenia, transformacji - uprawiania. To w związku z rolnictwem pojawia się określenie agricultura, jako świadectwo ściśle antropologicznego źródła tego, co na co dzień dostępne

\footnotetext{
${ }^{7}$ Tamże, s. 84-92.

${ }^{8}$ Dorst odwołuje się przy tym do Cycerona, choć pisarz ten kwestiami agrarnymi zajmował się niejako przy okazji. Za życia Cycerona ukazało się dzieło Marka Terencjusza Warrona, O gospodarstwie rolnym, ( wyd. polskie w tłum. I. Mikołajczyka, Ossolineum,Wrocław-Warszawa-Kraków 1991) a prawie sto lat później Lucjusz Juniusz Moderatus Kolumella napisał $O$ rolnictwie, (wyd. polskie w thum. I. Mikołajczyka, Ossolineum, Wrocław-Warszawa-Kraków 1991). Te poświęcone rolnictwu prace będące zarazem podręcznikami i filozoficznymi „wykładniami” dla pewnego aspektu bycia człowiekiem, uświadamiają znaczenie rolnictwa w kształtowaniu - mam nadzieję, że nie zabrzmi to zbyt patetycznie -człowieka. Listę starożytnych dzieł poświęconych rolnictwu otwiera epos Prace $i$ dnie Hezjoda (ok. 700 rok p.n.e.; Hezjod, Narodziny bogów (Theogonia). Prace $i$ dni. Tarcza, thum. J. Łanowski, Prószyński i Ska,Warszawa 1999).
} 
człowiekowi ${ }^{9}$. Już wówczas zdawano sobie sprawę, że przyroda w swym „surowym” stanie jest - by tak rzec - „niestrawna”, dlatego, najpierw kowalstwo, a potem rolnictwo były tymi działaniami człowieka, które przyrode „przyrządzaja” tak, aby była ona przyswajalna. Rolnictwo było wówczas efektem najbardziej wysublimowanej aktywności człowieka i mogłoby być traktowane właśnie jak rzemiosło - uprawianie roślin miało coś z uprawiania sztuki i samo było sztuką ${ }^{10}$.

Pomimo głębokiej ingerencji w środowisko, antyczni Grecy zawsze zwracali uwagę na to, czy ich działalność nie wywoła gniewu bogów. Potrzeba przekształcania otoczenia i świadomość, że jest ono tworem bóstw, a więc czymś uświęconym i nietykalnym jest źródłem konfliktu na miare greckiej tragedii. $\mathrm{Z}$ jednej bowiem strony działania Greków były dyktowane ludzkimi potrzebami, a $\mathrm{z}$ drugiej były krępowane boskimi prawami. Ale i z tego konfliktu Grecy znaleźli racjonalne wyjście, otóż - jak pisze Lidia Winniczuk - „melioracje typu osuszania i nawadniania terenów nie były w pojęciu Greków łamaniem praw przyrody ani znieważaniem bóstw, jednak czyny, które świadczyły o tym, iż człowiek w swej pysze ośmiela się dorównywać bogom, były uważane za świętokradzkie i należało obawiać się kary bogów" ${ }^{\prime 1}$. Przerzucenie mostu ponad cieśniną Bosfor przez Persów było już przekroczeniem kompetencji człowieka - tak więc, gdy Kserkses przegrał bitwę, jego klęskę tłumaczono gniewem bogów. O ile więc rolnictwo, które miało zapewnić przeżycie ludziom, było „tolerowane” przez bogów, o tyle tak śmiałe konstrukcje jak mosty budowane ponad morzem, łączące kontynenty, mogły znamionować czyny heroiczne, boskie - na miarę zuchwałej kradzieży ognia dokonanej przez Prometeusza. „Bóg oddzielił Azję od Europy przesmykiem morskim Hellespontu: nie wolno krzyżować jego niewiadomych nam zamiarów, łącząc sztucznie to, co on rozdzielił" ${ }^{12}$. Nietrudno jednak zauważyć, że przestrzegając praw boskich objawiających się w zastanym porządku przyrody i lękając się kary za ich naruszenie, człowiek nigdy nie dokonałby znaczących postępów. Grecy - tak sądzęrozdarci między zakazami bogów a ciekawością rozumu i praktycznymi

\footnotetext{
${ }^{9}$ Agricultura oznacza uprawę roli i składa się z dwóch wyrazów: ager - pole, colo zajmować się, dbać o coś (w sensie materialnym lub moralnym). Por. Stownik łacińskopolski, red. M. Plezia, t. 1, PWN, Warszawa 1998.

${ }^{10} \mathrm{O}$ tym, że rolnictwo było sztuką i wymagało wiedzy, tradycji, osprzętu świadczył fakt, iż wraz z upadkiem Cesarstwa Rzymskiego spadła także wydajność i jakość rolnictwa.

${ }^{11}$ L. Winniczuk, Ludzie - Zwyczaje i obyczaje - Starożytnej Grecji i Rzymu, wyd. 2., PWN, Warszawa 1983, część I, s. 38.

${ }^{12}$ L. Winniczuk, Ludzie..., dz. cyt., s. 39.
} 
potrzebami, nieustannie przekraczali granice tego, co boskie, ale zawsze $\mathrm{z}$ balastem uniemożliwiającym im swobodne i nieograniczone działanie.

Urządzanie świata na ludzką miarę przejawiało się także w architekturze - każdy budynek, plac i miasto jako całość organizowało przestrzeń zgodnie $\mathrm{z}$ jakimś planem. Koncepcja miasta idealnego wyrażała ową potrzebe przeformułowania dzikiej i niezorganizowanej przyrody w świat geometrycznych idei, podporządkowanych regułom Rozumu.

Gdy Franciszek Bacon sformułował zadania nowej nauki wpisał się, do pewnego stopnia, w tradycję reprezentowaną przez Greków, a przede wszystkim przez Rzymian. Odtąd cała przyroda miała być czymś w rodzaju żyznego pola, podlegającego uprawie, przekształcanego i dopasowywanego do potrzeb i oczekiwań człowieka. Już nie tylko Bóg i racje rozumu uzasadniały zagospodarowanie przyrody. Bacon zwrócił uwage na społeczne potrzeby; uwolniwszy się od bezpośredniej zależności nieprzewidywalnej i złowrogiej natury, człowiek uwolni się tym samym od dręczących go plag - głodu, biedy, wojen, nierówności społecznych. Ta możliwość uniezależnienia się od zagrożeń ze strony przyrody, była dla tego filozofa czymś, co nazwalibyśmy dzisiaj „kryterium jakości życia”. W tych słowach wyraził swoje przekonanie w tej kwestii: ,,jeśli ktoś rozważy, jak wielka zachodzi różnica między życiem ludzi w jakiejś najbardziej cywilizowanej prowincji Europy z jednej strony, a w jakiejś najbardziej dzikiej i barbarzyńskiej okolicy Nowych Indii z drugiej, dojdzie on do przekonania, że różnią się one tak bardzo [...] nie tylko ze względu na pomoc i dobrodziejstwo, lecz także w wyniku porównania ich warunków życiowych. A sprawiają to nie ziemia, nie klimat, nie różnice cielesne, lecz kunszty"

Podobną filozofię nauki reprezentował Kartezjusz. To, co łączyło obu filozofów, mimo fundamentalnych różnic między nimi, to ich mechanicystyczna wizja przyrody oraz funkcja nauki jako narzędzia do jej przekształcania. Otóż właśnie owa korpuskularna struktura natury (niezależnie od tego czy jest w niej próżnia, czy nie) umożliwia manipulowanie nią. Innymi słowy, tak skonstruowana ontologia świata przyrody sprzyja jej przekształcaniu, natura jest niejako immanentnie przygotowana na transmutacje, transformacje, ewolucje itp. Co więcej, sprowadzona $\mathrm{w}$ filozoficznej wizji do mechanizmu, nadaje się do rekonstrukcji i naprawy, a tym samym człowiek znajduje uzasadnienie dla swojej eksploatacji otoczenia. Przyznając jednak naturze status mechanizmu, usunął potrzebę (i możliwość) aksjologicznej refleksji nad własnym stosunkiem do przyrody. Maszynie (takiej jak zegar czy krosno) nie „przysługuje”

\footnotetext{
${ }^{13}$ F. Bacon, Novum Organum, thum. J. Wikarjak, PWN, Warszawa 1955, s. 158-159.
} 
prawo do uwzględniania jej własnych potrzeb, ograniczeń czy „wytrzymałości". Zepsuty mechanizm można naprawić lub wyrzucić ${ }^{14}$.

W europejskiej wizji przyrody i filozofii wiedzy naukowej funkcjonował również nurt odmienny od dotychczas prezentowanego. Przez setki lat na gruncie kultury europejskiej rozwijała się myśl alchemiczna, niekiedy skrajnie odmienna w swoim podejściu i traktowaniu natury od mechanicystycznej, a później stechnicyzowanej wiedzy naukowej ${ }^{15}$. W tradycji alchemicznej cała przyroda, Ziemia i kosmos postrzegane były jak jeden organizm. W związku z tym, należało traktować je jak żywą istotę; nie funkcjonował podział na przyrodę ożywioną i nieożywioną, martwą i żywą materię.

Te wiążące się bezpośrednio $\mathrm{z}$ nauką filozoficzne idee, które zaowocowały powstaniem cywilizacji technicznej i przekształceniem jej w cywilizację technologiczną ${ }^{16}$, przyniosły jeszcze coś więcej ${ }^{17}$. Otóż, poza ewidentnym antropocentryzmem i europocentryzmem (w skrajnym przypadku nazwałbym to zachodnio-europocentryzmem), pojawił się postulat swoiście pojmowanego „eksportu” postępu technicznego i naukowego. Wynikało to nie tylko z faktu, że Europejczycy zasiedlali wszystkie zakątki znanego wówczas świata, a więc importowali udogodnienia wytworzone na „starym kontynencie” (czując się zapewne

\footnotetext{
${ }^{14} \mathrm{~W}$ przypadku Kartezjusza, siłę jego filozoficznej wizji świata przyrody wzmacniała idea jej matematyzacji. Eksperymentalizm i indukcjonizm, które postulował Franciszek Bacon wymagały, przynajmniej w założeniach, kontaktu $\mathrm{z}$ naturą, zmierzenia się $\mathrm{z}$ jej „materią", gdy tymczasem matematyczna metoda praktycznie ograniczała ten wymóg do minimum, a nawet go eliminowała. O płynących stąd zagrożeniach dla relacji z przyrodą, a w konsekwencji dla człowieka i jego kultury pisał także Edmund Husserl w cytowanej już książce Kryzys nauk europejskich i fenomenologia transcendentalna.

15 Myślenie alchemiczne nie jest oczywiście wytworem kultury europejskiej ichronologicznie znacznie wyprzedza intelektualny dorobek Europejczyków. Funkcjonował pewien nurt alchemii ściśle związany z Europa, który powstał jako konglomerat filozofii Arystotelesa, filozofii Bliskiego Wschodu, mitów i religii chrześcijańskiej, i który kojarzy się najczęściej z działaniami prowadzącymi do uzyskania złota $\mathrm{z}$ innych metali.

${ }^{16}$ Do pewnego stopnia każda cywilizacja była „techniczna”, tak jak cywilizacje starożytnego Egiptu, Sumerów, Grecji, a także Majów, Inków itd. Różnica między tymi dawnymi cywilizacjami a nowożytną cywilizacją europejską polegała na tym, że stosowanie techniki w działaniach człowieka zostało w Europie uznane za istotny i niezbędny element kultury europejskiej. Co więcej, immanentną cechą tak rozumianej technicyzacji stał się jej ciagły rozwój, ciagłe udoskonalenia, coraz większa skuteczność, a wreszcie wszechstronne teoretyczne opracowanie; T. Kuhn, Tradycje matematyczne a tradycje eksperymentalne w rozwoju nauk fizycznych, [w:] Dwa bieguny: tradycja i nowatorstwo w badaniach naukowych, tłum. S. Amsterdamski, PIW, Warszawa 1985.

${ }^{17}$ J. Dorst, Sita.., dz. cyt., s. 92-94.
} 
w naturalny sposób dziedzicami tego, co w Europie powstawało) nie tylko ze względów ekonomicznych, lecz także religijnych. Sądzę, że w tym „eksporcie” techniki realizowała się jakaś forma ewangelicznego wezwania do głoszenia „dobrej nowiny” wśród wszystkich narodów świata. Oczywiście pod nadzorem Europejczyków ${ }^{18}$. „Eksportowi” techniki towarzyszył także „eksport” idei filozoficznych i naukowych, idei europejskiego modelu państwa, który w praktyce oznaczał kolonializm, choć w konsekwencji przyniósł również idee demokratyczne. Przybycie Europejczyków i wcielanie w życie europocentrycznego poglądu na przyrodę, człowieka i religię prowadziło nieuchronnie do zniszczenia nie tylko środowiska naturalnego, ale także struktur i więzi społecznych oraz zerwania ciagłości kulturowej, wskutek zakazu praktyk i wierzeń magicznych zakorzenionych w mitach rdzennej ludności. Ów wymiar społeczny odnosił się także do geograficznie rozumianej przestrzeni życiowej. Każda społeczność, każde plemię zajmowało jakiś określony teren. Co więcej, zasiedlenie tego, a nie innego obszaru, miało swoje transcendentne uzasadnienie - ziemię nadał Bóg, bogowie, Duch. To owe pozaziemskie istoty zamieszkiwały te tereny, przekazując je $\mathrm{w}$ spadku mitycznym przodkom współczesnych mieszkańców, a ci z kolei pozostawiali ją swoim następcom. Taka sukcesja trwała przez pokolenia i każda zmiana wiązała się $\mathrm{z}$ rugowaniem dotychczasowych włodarzy. Oczywiście najeźdźcy, najcześciej, także szukali jakiegoś mistycznego, filozoficznego, ideologicznego uzasadnienia prowadzonej aneksji. Dzieje ludzkości przepełnione były i są takimi działaniami - od czasów starożytnego Egiptu i Sumeru, przez Anschlus Austrii dokonany pod przywództwem Hitlera, aż po dzisiejsze wydarzenia na wschodzie Ukrainy. Niszczono $\mathrm{w}$ ten sposób pewien ład prawny, wypracowywany przez wieki, niekoniecznie artykułowany, zwykle kreowany i utrwalany w sposób naturalny. Ziemia, odziedziczona po bogach, stawała się w końcu towarem, podlegającym wycenie i obrotowi, a znaczenie samej przyrody zredukowano do merkantylnej wartości.

Jednakże Dorst zwraca przy tym uwagę, że nawet wschodnie religie, głoszące metempsychozę i panteizm, nie uchroniły dawnych cywilizacji przed degradacją środowiska i ich upadkiem. Niezależnie od tego jakie były źródła ekologicznej klęski cywilizacji Khmerów, północnozachodnich Indii, a nawet Majów (o tym w dalszej części artykułu), to już w tej chwili możemy stwierdzić, że to, co różniło podejście do

\footnotetext{
${ }^{18}$ Prymat Europejczyków w ewangelizowaniu świata przejawia się także w tym, że na przykład pierwszy czarnoskóry ksiądz został wyświęcony w Stanach Zjednoczonych w 1885 roku.
} 
przyrody tych cywilizacji i cywilizacji europejskiej, to właśnie filozoficzna, ideologiczna podbudowa. Eksploatacja zasobów przez dawne cywilizacje nie była efektem nakazu czy wezwania w imię lepszej przyszłości, a aktywne wykorzystywanie przyrody nie miało zaplanowanego charakteru. Była to całkiem naturalna działalność zapewniająca egzystencję. $Z$ drugiej strony należy też podkreślić, o czym często zapomina się szczególnie w przypadku biblijnego wezwania do „czynienia sobie ziemi poddaną", że nie możemy stwierdzić, aby jawnie nawoływano do czegoś, co nazwalibyśmy dewastacją przyrody.

Sądzę jednak, że właśnie to świadczy o tym, iż degradacja środowiska, skoro nie jest wpisana $\mathrm{w}$ imperatyw jego eksploatacji, jest wynikiem ubocznym ludzkiej działalności i niestety raczej nieuchronnym. Można oczywiście zapytać, czy sygnalizowana tu destrukcyjność ludzkiego działania jest rzeczywiście nieuchronna, czy też pojawia się dopiero w pewnych okolicznościach?

Opisując odmienne przeświadczenia i idee w odniesieniu do przyrody oraz idące $\mathrm{w}$ ślad za tym relacje $\mathrm{z}$ nią, można zauważyć jaki miały one wpływ na postawę wobec natury, a w konsekwencji na jej status - antropologiczny i ekologiczny, epistemologiczny i ontologiczny, wreszcie ekonomiczny i prawny prawny.

Przyrodę zatem postrzegano i traktowano jako:

- transcendentną, jako źródło hierofanii i epifanii,

- źródło praktycznej działalności człowieka, jako teren eksploatacji ${ }^{19}$,

- źródło i przedmiot poznania, jako wartość (także poznawcza) sama w sobie, bez względu na praktyczne korzyści,

- źródło inspiracji i przeżyć estetycznych, jako obiekt i narzędzie artystycznej ekspresji.

Zmiana naszego stosunku do przyrody, skutkowała zmianą jej statusu, odrzuceniem jednych względem niej zakazów i nakazów, a przyjęcie innych. W kulturze europejskiej trudno jednak było zbudować nowe relacje z przyrodą, skoro owe wezwanie biblijne było aż tak głęboko zakorzenione, że Franciszek Bacon $\mathrm{z}$ całym przekonaniem mógł stwierdzić: „niechaj tylko ród ludzki odzyska swoje prawa w stosunku do przyrody, jakie mu się należą z boskiego nadania oraz ma

\footnotetext{
${ }^{19}$ Można powiedzieć, że przyroda swoją obecnością prowokuje do działania skierowanego ku niej samej. Kwintesencją takich motywów działania była odpowiedź alpinisty, który na pytanie o to, dlaczego zdobywa góry, stwierdził: „bo one są”.
} 
całkowitą swobodę w korzystaniu z nich, a sposobami wyzyskania ich kierować będzie zdrowy rozsądek i prawdziwa religia ${ }^{20 "}$.

Sądzę, że w wielu sytuacjach zawiódł i „zdrowy rozsądek”, i ,prawdziwa religia”.

\section{Na czym polega destrukcyjne dzialanie czlowieka wobec przyrody?}

Wszystkie światopoglądy - jak zauważa Dorst - funkcjonujące w Europie na przestrzeni dziejów nie sprzyjały ochronie środowiska. Nawet te, które faktycznie czyniły z niego miejsce bytowania bóstw i podkreślały jedność człowieka z przyrodą.

Jak w takim razie rozumieć ową destrukcyjność, na czym miałaby ona polegać? Czy pojęcie destrukcji ma charakter ponadczasowy i ponadkulturowy, czy też pojawia się dopiero w pewnych warunkach, na przykład zmiany oczekiwań wobec przyrody lub dopiero w perspektywie zmian dostrzeganych w samej przyrodzie, i to zmian o określonym kierunku i natężeniu. Pojęcie destrukcji, degradacji jest wartościujące i hierarchizujące; jest więc aksjologicznie zabarwione. Pojęcie degradacji niesie ze sobą względność: coś może być zdegradowane ze względu na coś lub względem czegoś; to, co jest degradacją dla jednego organizmu, jest korzyścią dla innego.

Nie zapominajmy przy tym, że wszystkie zwierzęta i rośliny zmieniają swoje otoczenie. I w tym wypadku jakakolwiek aktywność jednych organizmów, powoduje zmiany niekorzystne dla innych. Realizacja jednych potrzeb odbywa się kosztem innych - ogranicza, bądź wyklucza możliwość zaspokajania koniecznych do przeżycia czynników kolejnym organizmom. W otaczającym nas świecie mamy „nieskończenie” wiele takich przykładów. Oto drzewa porastające łąkę tworząc las, eliminują trawy, tworząc własny ekosystem niezbyt przyjazny dla roślin trawiastych. Mrowiska i termitiery są wysoce skomplikowanymi konstrukcjami powstałymi w wyniku przetworzenia naturalnych elementów, stanowiąc przy tym względnie odizolowany świat. Podobnie żeremia i tamy bobrów, a także ptasie gniazda są konstrukcjami, które na pewien czas i w różnej skali tworzą własne środowisko. Ale i w tych przypadkach widzimy negatywne dla otoczenia konsekwencje. Piętrząc wodę, bobry zalewają okolicę niszcząc rosnące w pobliżu drzewa, krzewy i trawy, a także żyjące zwierzęta (praktycznie cały edafon). Żyjące kolonijnie ptaki, podobnie jak bobry i termity, potrafią przekształcać zatruwając najbliższe otoczenie - wieloletnie kolonie kormoranów niszczą las,

${ }^{20}$ F. Bacon, Novum..., dz. cyt., s. 160. 
w którym są założone. Ptasie odchody sprawiają, że las umiera, a gniazda pozostają na martwych, wysuszonych, bezlistnych drzewach. Na „mniejszą skalę" niszczą swoje otoczenie pasożyty. Potrafią doprowadzić do śmierci swojego gospodarza i to niezależnie od tego, czy są wewnątrz niego, czy nie.

W historii Ziemi dokonała się już raz globalna przemiana spowodowana aktywnościa organizmów. Przejście do atmosfery tlenowej zawdzięczamy cyjanobakteriom, które $\mathrm{w}$ procesach fotosyntezy wiązały dwutlenek węgla, a wydalały tlen. Powstały one prawdopodobnie $\mathrm{z}$ bakterii siarkowych zdolnych do fotosyntezy w warunkach beztlenowych w obecności siarkowodoru. Skamieniałości po tych bakteriach (stromatolity) mają ok. 3 miliardów lat. Po około 2 miliardach lat stężenie tlenu wynosiło ok. $10 \%$ dzisiejszego, wystarczyło to jednak na wytworzenie warstwy ozonu i oddychania tlenowego ${ }^{21}$.

Człowiek, jak każdy organizm, eksploatował przyrodę by zapewnić byt. Gdy jednak zaczął zdawać sobie sprawę z przypadkowości środków, dzięki którym mógł zaspokajać swoje potrzeby, w przeciwieństwie do innych gatunków, przestał być biernym konsumentem, uzależnionym całkowicie od „oferty” przyrody - zaczął ją przekształcać zmieniając swoje otoczenie. Jako istota rozumna potrafił przewidywać, a tym samym zaplanować, a zapewnienie ciagłości, choćby pożywienia, wiązało się $\mathrm{z}$ zapewnieniem poczucia bezpieczeństwa własnej egzystencji, co w konsekwencji wpływało na polepszenie warunków życia. Podjęte w tym celu działania musiały dążyć do takiego przekształcania otoczenia, by stało się ono bardziej przyjazne i wydajne. Okazało się jednak,

\footnotetext{
${ }^{21}$ Por. W. J. H. Kunicki-Goldfinger, Znikad donikad, wyd. 2., PIW, Warszawa 1993, s. 143-145; także P. Ward, Hipoteza Medei, tłum. M. Betley, Prószyński i S-ka, Warszawa 2010, s. 81-93; F. Crick, Istota i pochodzenie życia, tłum. A. Hoffman, PIW, Warszawa 1992, s. 83-88.

Należy jednak podkreślić, że to, co różni aktywność zwierząt od działania człowieka to fakt, że zwierzęta nie reflektują swoich poczynań i nie przewidują ich skutków, choć ponoszą konsekwencje zmian, jakie same wprowadziły. U podstaw ich działania nie leży żadna idea czy filozofia, a jeżeli już, to jedyną filozofią jest - przeżyć, czyli nie dać się zjeść. Niezależnie od tego możemy powiedzieć, że także zwierzęta polepszają swoje warunki życia.

Zmiany są też wynikiem czynników abiotycznych. Każdy z nas zdaje sobie sprawę z destrukcyjnego, niszczycielskiego działania wód, wiatrów, wulkanów, lodu itd. To te zjawiska kształtowały i nieustannie wpływają na krajobraz Ziemi. Człowiek, choć stara się im przeciwstawić lub przynajmniej zmniejszyć skutki ich działania, to ostatecznie, w skrajnych przypadkach, tę konfrontację przegrywa. Problemem naszej cywilizacji jest to, że bezmyślnie wydaje się olbrzymie środki na tę walkę, którą ostatecznie w dalszej perspektywie, człowiek - na lokalną, a być może i globalną skalę - musi przegrać. Wobec niektórych zjawisk jesteśmy bezbronni tak samo, jak nasi odlegli przodkowie.
} 
że wszelkie zmiany w środowisku przyrodniczym prowadzą w konsekwencji do efektów odwrotnych od oczekiwanych. Nawet wtedy, gdy skutki odroczone są w czasie (jak w przypadku naszej cywilizacji) i prowadzą do jego degradacji w stopniu zagrażającym egzystencji człowieka, a w konsekwencji pogarszającym jego byt.

Dlaczego zmiany prowadzące do polepszenia egzystencji ludzi stanowią zagrożenie dla środowiska? Dlatego, że wiążą się z jego eksploatacją i najczęściej z nieustannym jej wzrostem -ilościowym i jakościowym. Odnosi się to do wszystkich cywilizacji, choć niektóre idee, systemy społeczne i gospodarcze, jak już o tym wspomniano, moga dodatkowo wzmacniać i stymulować eksploatację środowiska, a tym samym przyśpieszać jego degradację ${ }^{22}$. Postęp zatem, poprawa warunków własnej egzystencji, zaspokajanie potrzeb zawsze realizuje się w drodze konfrontacji - wynika to ze sprzeczności ,interesów” człowieka i natury, a generalnie różnych organizmów ${ }^{23}$. Konflikty te mogą funkcjonować $\mathrm{z}$ różnym natężeniem i w różnym czasie, ale zawsze ktoś lub coś ponosi tego konsekwencje. Oczywiście koegzystencja do pewnego stopnia jest możliwa i zachodzi w świecie, wydaje się jednak, iż zawsze ma ona charakter „lokalny”.

Minione cywilizacje na tle współczesnej, globalnej „megacywilizacji" wydają się być neutralne wobec środowiska, a przynajmniej o niewielkiej dla niego szkodliwości. Tymczasem Dorst, przywołując przykłady z przeszłości, stara się jednoznacznie ukazać pewne ponadczasowe, ponadkulturowe mechanizmy odpowiedzialne za ekologiczna katastrofę i kres kwitnących kultur. Warto zatrzymać się na chwilę, by przyjrzeć się jak Dorst diagnozuje przyczyny ich upadku, jak wiąże czynniki ideologiczne, gospodarcze i ekologiczne oraz jakie znaczenie w tym wszystkim przypisuje eksploatacji środowiska przyrodniczego.

\footnotetext{
${ }^{22} \mathrm{Z}$ drugiej strony, tworzone i funkcjonujące w każdej cywilizacji zakazy i nakazy regulujące stosunki człowieka $\mathrm{z}$ przyrodą, mogą spowalniać i łagodzić skutki tych oddziaływań. Ustanowienie „świętych gajów”, „świętych zwierząt” lub „zwierzy królewskiej" może przyczynić się do ich ochrony, a nawet polepszyć ich byt.

${ }^{23}$ Zważywszy na to, że środowisko zmieniają zarówno zwierzęta jak i czynniki abiotyczne, staje się problematyczne czy możemy w stosunku do działań zwierząt, a tym bardziej do zachodzących zjawisk atmosferycznych, geologicznych itp., używać pojęcia destrukcji. Innymi słowy, mówiąc o negatywnym, destrukcyjnym wpływie na przyrodę skutków działania jej wytworów, w jakim sensie możemy czy powinniśmy rozumieć to pojęcie?
} 


\section{Kres cywilizacji - problem nie tylko przeszłości}

Poszukując przykładów z przeszłości, Dorst odwołuje się do zdarzeń, które miały miejsce $\mathrm{w}$ różnym czasie pod różnymi szerokościami geograficznymi. Kreśli dzięki temu bardzo uniwersalny obraz - żadna cywilizacja nie jest absolutnie odporna na zmiany środowiska i każda, prędzej czy później, odczuje skutki własnej działalności ${ }^{24}$. Przywołując konkretne przykłady celnie oddaje problem sygnalizując go w tytułach podrozdziałów - Świat śródziemnomorski ofiarq siekiery i kozy, Cywilizacja Khmerów albo skutki nadmiernego wzrostu gospodarczego lub Imperium Majów albo szaleństwo erozji. To, co ostatecznie powtarza się w diagnozie Dorsta, to fakt nadmiernej, niepohamowanej eksploatacji środowiska przyrodniczego. Przebiegała ona w różny sposób i w odmiennych warunkach przyrodniczych, dlatego też miała w każdym przypadku indywidualny charakter, choć ostatecznie ten sam skutek. Przyjrzyjmy się kilku przykładom.

Cywilizacja Khmerów ${ }^{25}$ rozwijała się na obszarze dzisiejszej Kambodży oraz Myanmaru, Laosu, Tajlandii, Wietnamu i Malezji. Obejmowała więc praktycznie całą południowo-wschodnią Azję. Jak podkreśla Dorst, pod względem przyrodniczym centrum tej cywilizacji ulokowane zostało na rozległej równinie, nad brzegiem jeziora Tonle Sap. Był to obszar pierwotnie pokryty lasami deszczowymi, w strefie monsunów. I to właśnie położenie stanowiło największy problem - nierównomierny rozkład opadów. W porze monsunowej obfite opady zapewniają nadwyżkę wody, za to w porze suchej zawsze jej brakuje. Należało zatem rozwiązać kwestię jej gromadzenia i dystrybucji. W tym celu wybudowano rozległą sieć zbiorników retencyjnych i kanałów irygacyjnych, które do dziś są cudem techniki. Coraz większa i wydajniejsza infrastruktura hydrotechniczna umożliwiała wzrost produkcji rolnej, co z kolei sprzyjało wzrostowi demograficznemu. To zaś wymagało zwiększenia produkcji rolnej, a zatem powiększenia areału upraw i rozbudowę systemu irygacyjnego, a w konsekwencji powodowało przekształcanie zalesionych terenów w uprawy i zbiorniki retencyjne. Efektem był wzrost produkcji rolnej, nadwyżka żywności, wzrost demograficzny, a to wymagało dalszych prac i nakładów na rozwój rolnictwa i hydrozabudowy.

Nietrudno się domyślić, jaka konkluzja może wypływać $\mathrm{z}$ takiego rozwoju wydarzeń. W miarę upływu czasu (ok. trzy stulecia) anektowano coraz to nowe obszary pierwotnego lasu, zakłócając tym samym naturalny obieg wody w przyrodzie. Pojawił się także dodatkowy czynnik -

\footnotetext{
${ }^{24}$ J. Dorst, Siła.., rozdz. III: Btędy ekologiczne a upadte cywilizacje, dz. cyt.

${ }^{25}$ Tamże, s. 47 i n.
} 
odsłonięte tereny sprzyjały erozji gleby, która powodowała zamulanie zbiorników i kanałów, a tym samym ich niewydolność, co wymuszało ich renowację i rozbudowę. Do tego doszło jeszcze jedno niekorzystne zjawisko - otóż pierwotnie spływające wody niosły ze sobą żyzne czerwone iły. W miarę rozbudowy systemów irygacyjnych, większa część tych zawiesin osadzała się w górnych partiach kanałów i zbiorników, wskutek czego do pól docierała „wyjałowiona” woda. Spadała więc produktywność rolnictwa, która wymagała kolejnej rozbudowy urządzeń hydrotechnicznych. Cywilizacja Khmerów wygenerowała pewnego rodzaju agrarno-techniczno-demograficzne błędne koło, którego w końcu padła ofiarą. Zapewne w ówczesnej sytuacji nie było $\mathrm{z}$ niego wyjścia. „Bezpośrednimi przyczynami upadku państwa khmerskiego - podsumowuje Dorst - były, jak dowodzą historycy, czynniki polityczne i socjologiczne. Przyczyn ostatecznych należy szukać w gigantyzmie systemów, które miały umożliwić wykorzystywanie zasobów naturalnych ponad granice możliwości” ${ }^{26}$. Możliwości środowiska przyrodniczego należałoby dodać.

Kolejny przykład to północno-zachodnie Indie ${ }^{27}$, czyli obszar dzisiejszego Pakistanu i przyległych terenów Indii. Paradoksalne jest to, że kraina rozciagająca się wzdłuż Indusu, z dużą wilgotnością powietrza, jest dziś wysuszoną i jałową ziemią. Badania palinologiczne ${ }^{28}$ ukazują odmienne oblicze tej krainy w nieodległej przeszłości. Otóż okazuje się, że była ona pokryta bujną, tropikalną roślinnością, która z czasem zmieniała się w słonorośla, a następnie $\mathrm{w}$ pustynię pokrywającą ją od $\mathrm{X}$ wieku naszej ery. Jak to się stało? Diagnoza Dorsta (za R.A. Brysonem ${ }^{29}$ ) jest zaskakująca: odpowiedzialna za pustynnienie tych obszarów jest zachwiana równowaga termiczna i higrometryczna atmosfery ${ }^{30}$. Nie wdając się w szczególy procesów powodujących kondensację pary wodnej w atmosferze i powstawanie deszczu, wystarczy powiedzieć, że brak opadów jest skutkiem intensywnych wypasów i w konsekwencji coraz większej erozji wietrznej gleby, unoszącej do atmosfery tony pyłów. Zmniejszenie ilości opadów spowodowało spadek produkcji rolnej i ho-

\footnotetext{
${ }^{26}$ Tamże, s. 52.

${ }^{27}$ Tamże i $\mathrm{n}$.

${ }^{28}$ Dział botaniki zajmujący się badaniem pyłków kwitowych, także kopalnych. Por. paleobotanika.

${ }^{29}$ Dorst powoluje się na artykuł R. A. Bryson`a, Climate modification by air pollution, [w:] The Enviromental Future, red. N. Polunin, Macmillan, London 1972.

${ }^{30}$ J. Dorst, Siła.., s. 53 i n. Powstawanie opadów atmosferycznych jest procesem bardzo skomplikowanym i zależy od wielu czynników, między innymi od obecności tak zwanych ,jąder kondensacji”, którymi mogą być mineralne frakcje, jak i drobnoustroje.
} 
dowli. Aby się temu przeciwstawić, człowiek „,nasilił wtedy jeszcze swą działalność, stale pogłębiając tym samym skutki erozji”31. Znowu mamy do czynienia z błędnym kołem przyczyn i skutków, które sprzęgają się w nierozerwalnych zależnościach, pogłębiając w każdym cyklu już istniejące problemy: wypasanie - erozja - brak opadów, coraz intensywniejsze wypasanie - coraz intensywniejsza erozja - coraz mniejsze opady.

W rozdziale poświęconym starożytnej Grecji, Dorst opisuje podobny mechanizm. Nadmierny wyrąb bujnych lasów porastających góry i wypas na powstałych porębach przyczyniły się do degradacji środowiska. Choć zdania są podzielone co do ostatecznych przyczyn tego zjawiska, czy są one naturalne czy też antropogeniczne, to zarówno w przypadku obszarów wokół Indusu jak i basenu Morza Śródziemnego „człowiek potrafi jednak z pomocą zabiegów pielegnacyjnych i zdrowej gospodarki wodą hamować lub nawet powstrzymywać procesy szkodliwe dla jego interesów, albo też przeciwnie - przyśpieszać je przez wyczerpywanie zasobów naturalnych"32.

Prześledźmy jeszcze jeden, bardzo znamienny przykład. Imperium Majów ${ }^{33}$ obejmowało obszar półwyspu Jukatan (dzisiejszy Meksyk) oraz północne części Gwatemali. Geograficznie i przyrodniczo usytuowane było podobnie jak cywilizacja Khmerów - w strefie lasów deszczowych i monsunów. Tak więc i w tym przypadku mamy do czynienia $\mathrm{z}$ dwiema porami - deszczową i suchą, co rodziło podobne problemy, nadmiar wody podczas monsunów i ich niedobór w pozostałej części roku. Mieszkańcy musieli zatem magazynować wodę, cześciowo w naturalnych studniach, a częściowo w „cysternach i zbiornikach”. I także tu rozkwit cywilizacji Majów wiązał się z rozwojem rolnictwa i wzrostem demograficznym. Oba te czynniki wymagały coraz bardziej rozbudowanego systemu magazynowania i dystrybucji wody, co wiązało się z ogromnymi przedsięwzięciami hydrotechnicznymi pochłaniającymi nowe obszary i zasoby środowiska naturalnego. Do tego dochodził negatywny wpływ na środowisko spowodowany specyfiką uprawy kukurydzy. Roślina ta rośnie w uprawach dość rzadko, odsłaniając połacie gleby i narażając ją na wypłukiwanie. Gdy zaczęto uprawiać ją na górskich zboczach, erozja nasiliła się. Spływająca po stoku woda nie miała już naturalnych ograniczeń - rosnący wcześniej las zatrzymywał spływ i magazynował wodę. Ukształtowanie powierzchni przypomina Grecję, ale klimat tereny zamieszkane przez Khmerów - oba te czynniki, zdecy-

\footnotetext{
${ }^{31}$ J. Dorst, Siła.., dz. cyt., s. 54.

${ }^{32}$ Tamże, s. 47 oraz ostatni akapit s. 54.

${ }^{33}$ Tamże, s. 58 i n.
} 
dowanie niekorzystne dla gospodarki rolnej, prędzej czy później musiały doprowadzić do jej zachwiania, a w konsekwencji do upadku Majów. Ale to nie wszystko - zamulone kanały utrudniały żegluge, transport i komunikację, a tym samym funkcjonowanie administracji; następnie zarastanie jezior sprzyjało rozmnażaniu się owadów przenoszących choroby - malarię i żóltą febrę, wyniszczając biologicznie ludzi. „Wiele przyczyn - pisze Dorst - wymieniano by wyjaśnić nagły upadek (Majów - Z.P.). Mówiło się o kryzysach kulturalnych, społecznych, demograficznych, o napięciach między klasami i klanami [...] Wielu sądzi jednak, że pierwotną przyczyną kresu tej wspaniałej kultury było niewłaściwe wykorzystanie środowiska naturalnego, $\mathrm{z}$ pewnością związane $\mathrm{z}$ nieproporcjonalnym wzrostem liczby ludności" ${ }^{34}$. Podobnie jak w poprzednich przypadkach tak i w tym okazuje się, iż imperium Majów musiało upaść, bowiem eksploatacja zasobów naturalnych uruchomiła procesy degradujące środowisko, a także osiagnęła poziom „wydajności” ekosystemu, uniemożliwiając mu samoregenerację ${ }^{35}$.

Wymieniając różne powody kryzysów i upadku tych cywilizacji, zawsze pojawia się, jako pierwotna, jedna przyczyna - były nią błędy ekologiczne $^{36}$. Polegały one (i nadal polegaja) najczęściej na zachwianiu równowagi ekologicznej wskutek wyczerpywania zasobów naturalnych w efekcie nadmiernej eksploatacji ${ }^{37}$.

To, co rzuca się w oczy, gdy mówimy o mniej lub bardziej zaborczej eksploatacji środowiska $\mathrm{w}$ przeszłości, to fakt, że zawsze miała ona lo-

\footnotetext{
${ }^{34}$ Tamże, s. 60.

${ }^{35}$ Przy tej okazji można zapytać, dlaczego przetrwały inne starożytne cywilizacje, także przecież eksploatujące środowisko naturalne, jak choćby Chiny, Egipt czy nawet wspomniana już Grecja. Państwa te nie runęły w jakiś ostateczny i nieodwracalny sposób. Przeżywając kryzysy gospodarcze, polityczne i ekologiczne funkcjonowały nadal i są na politycznych mapach świata do dzisiaj. Odpowiedź na to pytanie, w pewnym sensie, wiąże się z funkcjonowaniem współczesnej cywilizacji. Ale też przypadek upadku Cesarstwa Rzymskiego uzmysławia nam, że za katastrofą tak wielkiego imperium nie muszą stać przyczyny ekologiczne; por. M. Cary, H. H. Scullard, Dzieje Rzymu, tłum. J. Schwakopf, PIW, Warszawa 1992, t. II, s. 428-430.

${ }^{36}$ Skupiłem się na omówieniu tych cywilizacji, które zajmowały obszary tropikalnych lub subtropikalnych rejonów świata. Postąpiłem tak dlatego, gdyż dzisiaj rejony te są terenem rabunkowej wręcz eksploatacji, a także dlatego, że nadal w powszechnie są one postrzegane jako bogate i żyzne, o nieograniczonej produktywności. Tymczasem środowisko na tych obszarach jest bardzo wrażliwe na wszelkie zachwiania równowagi i pod wieloma względami bardzo ubogie (na przykład gleby, nierównomierny rozkład opadów itd.).

${ }^{37}$ Dorst wielokrotnie powtarza, że należy brać pod uwagę także inne czynniki militarne, polityczne, demograficzne. Ale wszystkie one, będąc powiązane ze sobą, są także uzależnione od tego, co dzieje się z otaczającą nas przyrodą.
} 
kalny zasięg. Cywilizacje te korzystały z zasobów, które były zlokalizowane w pobliżu ośrodków władzy czy miast. Nawet jeżeli, tak jak cywilizacja Khmerów, rozciagały się na przestrzeni tysięcy kilometrów kwadratowych, to i tak bezpośrednim zapleczem gospodarczym były tereny przyległe, aż do ich maksymalnego wyjałowienia, po czym przenoszono się na kolejne najbliżej położone obszary itd. W rzeczywistości cywilizacje te były w pewnym sensie zamknięte i nawet jeżeli prowadziły handel i utrzymywały kontakty z odległymi państwami, to i tak - w skali kontynentu, a tym bardziej globu - miał lokalny charakter. I jeszcze jeden typowy dla nich rys. Otóż widzimy też, że w swej „walce” z przyrodą, $z$ jej ograniczeniami, dysponowały techniką, która praktycznie nie ulegała zmianie. Nowe okoliczności (wyższa demografia, nowe choroby, wyjałowienie gleb itd.) wymagały nowych, rewolucyjnych rozwiązań technicznych i idei. Tymczasem niczego takiego nie obserwujemy. Owe przełomowe rozwiązania techniczne i idee pojawiły się dopiero w Europie, w każdej dziedzinie i stały się źródłem cywilizacji o globalnym (a nawet wykraczającym poza Ziemię) charakterze ${ }^{38}$.

\footnotetext{
${ }^{38}$ Sposób, w jaki Europa dokonała tego przejścia od cywilizacji lokalnej do globalnej, w jaki ,uciekła” takim potęgom jak Chiny, Indie czy Arabowie, jest przedmiotem wielu analiz. Jednakże każda $\mathrm{z}$ nich musi uwzględnić te czynniki jakimi były filozofia, nauka i technika. Por. na przykład N. Ferguson, Cywilizacja. Zachód i reszta świata, thum. P. Szymor, Wydawnictwo Literackie, Kraków 2013; S. Greenblatt, Zwrot. Jak zaczal sie Renesans, tłum. M. Słysz, Wydawnictwo Albatros A. Kuryłowicz, Warszawa 2012. Istnieje także hipoteza, że za odmienną „osobowość” Europejczyków i na przykład, Chińczyków odpowiada rodzaj zbóż, które były przez nich uprawiane. Margit Kossobudzka w artykule Ryżowy wschód kontra pszeniczny zachód (Gazeta Wyborcza, piątek 16 maja 2014, s. 24-25) przedstawia badania przeprowadzone przez Thomasa Talhelma z Uniwersytetu stanu Wirginia w Charlottesville, który zbadał jaki wpływ na nasze myślenie (czy jest analityczne czy holistyczne), na nasze zachowanie, na stosunki społeczne, a tym samym na zdolność do podejmowania i realizowania różnych wyzwań, ma technika uprawy zbóż. Otóż twierdzi on, że uprawa ryżu wymaga dwukrotnie większego nakładu pracy (na jednostkę powierzchni, jednostkę masy itp.) niż uprawa pszenicy. Powoduje to potrzebę wspólnego działania - prace przy sadzeniu, nawadnianiu i żniwach angażują ludzi z całych wiosek (sprzyja to kolektywnemu działaniu i wymusza wzajemną sąsiedzką pomoc), natomiast „pszenica nawadnia się sama tym, co spadnie z nieba (a zatem) pszenicę może uprawiać jedna rodzina". Uprawa tego zboża sprzyja więc niezależności, indywidualności, samodzielności i przedsiębiorczości. A w opinii historyków, to te cechy są fundamentalne dla cywilizacji zachodniej.
} 


\section{Świat i współczesna cywilizacja}

Już pobieżna znajomość mechanizmów, wedle których funkcjonuje współczesna globalna cywilizacja, pozwala zauważyć, że dzisiejszy świat generuje wszystkie opisane wcześniej problemy, a tym samym zagrożenia - i to w dodatku na niewyobrażalną dla minionych państw skalę. Dotyczy to kwestii związanych $z$ dostępnością do słodkiej wody, zanieczyszczeniem wód powierzchniowych i podziemnych, zanikiem opadów atmosferycznych, a tym samym pustynnienia i erozji gleby, karczowaniem lasów, odpadami, no i wreszcie przeludnieniem. Wystarczy jednak krótka refleksja, by znaleźć odpowiedź na pytanie: jak to możliwe, że nie odczuwamy jeszcze efektów owego błędnego koła, w które wpadły minione imperia? Otóż to, że nasza cywilizacja nadal funkcjonuje, mimo tych wszystkich problemów, które położyły kres dawnym imperiom zawdzięczamy współczesnej technice i nauce. One także sprawiły, że cywilizacja nasza nabrała globalnego charakteru.

To, co charakteryzuje globalność w tym kontekście, to zdolność do pozyskiwania zasobów z każdego miejsca na Ziemi (ale, o czym należy mówić, także spoza niej). Współczesna cywilizacja nie jest wytworem wyłącznie Europy. Jednakże ze względu na znaczenie nauki i techniki i nie będzie to w tym przypadku wyrazem europocentryzmu - jej korzeni należy szukać w Europie. Podobnie jak w innych cywilizacjach, Europejczycy pierwotnie eksploatowali głównie to, co „podsuwała” im bezpośrednio przyroda - zwierzynę, drewno z lasów porastających cały kontynent, wodę, kamień, niektóre metale jak żelazo, miedź i złoto.

Początkowo Europejczycy kroczyli tą samą drogą, co minione i współczesne im cywilizacje, ale w każdej dziedzinie, „w którymś momencie" potrafili oni sprostać nowym wyzwaniom i nowym zagrożeniom dzięki nowym rozwiązaniom. Tak było w przypadku rolnictwa, eksploatacji zasobów naturalnych, rzemiosła, które przerodziło się w przemysł i dało początek technologii i technokracji.

Rolnictwo. Historycy dziejów człowieka twierdzą, że rewolucja neolityczna, czyli przejście od koczowniczo-pasterskiego trybu życia i gospodarki do rolnictwa, dokonało się na Bliskim Wschodzie i szybko zostało „zaszczepione” w całym basenie Morza Śródziemnego. Twierdza także, iż bezpośrednim skutkiem tej zmiany była nadwyżka żywności i wzrost demograficzny ${ }^{39}$. Tak jak w pozostałych częściach świata,

\footnotetext{
39 Jak widzimy, pod każdą szerokością geograficzną wydajne rolnictwo zawsze generuje wzrost populacji. Jednakże wzrost liczny ludności jest zawsze wrażliwy na
} 
wzrost produkcji rolnej wiązał się ze wzrostem areału upraw, co oznaczało, także w Europie, karczowanie lasów. To, co różniło Europę od opisanych wcześniej obszarów, to klimat i ukształtowanie terenu. Opady były tu rozłożone $\mathrm{w}$ miarę równomiernie, pory roku były wyraźnie odmienne, a większość powierzchni Europy stanowiły olbrzymie przestrzenie płaskiego lub lekko pofałdowanego terenu o w miarę żyznych glebach. Już same warunki naturalne stawiały rolnictwo europejskie $\mathrm{w}$ korzystniejszej sytuacji niż $\mathrm{w}$ innych rejonach ziemi. A jednak, po upadku Imperium Rzymskiego nastąpił gwałtowny spadek wydajności rolnictwa i powszechny niedostatek. Minęły wieki, nim rolnictwo odtworzyło się. Było to możliwe nie tylko dzięki nowym obszarom anektowanym pod uprawy (których nadal nie brakowało), nie tylko dzięki temu, że nie nastąpiła jakaś katastrofalna degradacja, lecz także dzięki temu, że pojawiły się nowe techniki upraw, zwiększających wydajność produkcji rolnej ${ }^{40}$.

To jednak, co uchroniło Europejczyków przed klęską głodu, a co nie stało się udziałem wcześniejszych cywilizacji, to odkrycie Ameryki oraz nawozów. Zwiększanie wydajności dzięki zastosowaniu, najpierw nawozów naturalnych, a później sztucznych, zapobiegło całkowitej dewastacji środowiska i do pewnego stopnia uniezależniło od warunków przyrodniczych. Idee Franciszka Bacona wcielane w życie już wcześniej, okazały się równie atrakcyjne i skuteczne $\mathrm{w}$ realizacji $\mathrm{w}$ gospodarce rolnej. W konsekwencji jednak, rodzące się współczesne rolnictwo przestało polegać na uprawie i hodowli, nie mogło już wyrażać się w formule cultura agrii, przerodziło się bowiem $\mathrm{w}$ przemysłową produkcję rolną i zwierzęca, tak samo jak rzemiosło i rękodzieło przerodziło się w przemysł i masową produkcję. Rośliny i zwierzęta faktycznie stały się maszynami, modyfikowanymi na wzór urządzeń technicznych, zgodnie z potrzebami i oczekiwaniami, wbrew ich naturze, wbrew ich fizycznej i psychicznej kondycji. Stały się produktami z taśmy montażowej, nad którymi obecnie pracują technicy i inżynierowie (także genetyczni), a nie

wahania zasobów pokarmu, które zależą głównie od nieprzewidywalnych i nie dających się kontrolować czynników przyrodniczych.

${ }^{40}$ Spadek wydajności rolnictwa wiązał się z ogólnym spadkiem kultury rolnej. „Po upadku cesarstwa rzymskiego metody rolnicze początkowo upadły, ale poczynając od IX i X w. wprowadzać zaczęto ulepszenia i proces ten trwał nieprzerwanie aż do czasów nowożytnych"; por. A. C. Crombie, Nauka średniowieczna i poczatki nauki nowożytnej, tłum. S. Łypacewicz, PAX, Warszawa 1960, t. 1., s. 230. Dalej Crombie wymienia, że do owych „ulepszeń" należy zaliczyć wprowadzenie pługa na kołach, zastosowanie płodozmianu i systemu trójpolowego, wykorzystanie konia jako zwierzęcia pociagowego, bronowanie itd. Por. s. 231-232, a generalnie cały rozdział Rolnictwo. 
przyrodnicy i rolnicy. Masowość tej produkcji w wielu rejonach świata wyeliminowała klęski głodu i wygenerowała wzrost konsumpcji, ale wygenerowała także nowe wyzwania - ekologiczne, naukowe i etyczne. Nie chodzi już tylko o to, w jakich warunkach trzymane są zwierzęta, jakimi środkami powinniśmy chronić uprawy, ale przede wszystkim o to, jakiego rodzaju pożywienie produkujemy, jak wpływa ono na nasze zdrowie i na, przepraszam za sformułowanie, ,jakość" przyszłych pokoleń. Innymi słowy - czym się tak naprawdę żywimy.

Eksploatacja zasobów naturalnych. To, co także łączy współczesną cywilizację i minione imperia, to eksploatacja zasobów naturalnych przy nieustannym jej wzroście.

Najszybciej i w największym stopniu pozyskiwano drewno - karczowanie lasów Europy zaczęło się już w starożytności, o czym wspomina Dorst pisząc o Grecji. Porastające cały kontynent lasy wydawały się niewyczerpanym bogactwem. Wylesianie bowiem trwało kilkanaście wieków i tylko w niektórych miejscach, jak na przykład w Wielkiej Brytanii, doprowadziło do całkowitej wycinki lasów, pozostawiając jednak w większej części Europy mniej lub bardziej rozległe kompleksy ${ }^{41}$. Ale i w tym wypadku ,z pomoca”" przyszły inne kontynenty. Na niespotykaną wcześniej skalę zaczęto wycinać i sprowadzać drewno ze wszystkich rejonów świata. Odkrycie Ameryki, coraz większa ekspansja w Afryce i Azji południowo-wschodniej, umożliwiła eksploatację zasobów lasów tropikalnych, oddalając widmo całkowitego wylesienia własnych państw. W zależności od warunków klimatycznych, topograficznych i technicznych, eksploatacja lasów przebiegała w różnym tempie. Najszybciej jej skutki można było zauważyć we wschodniej części Ameryki Północnej względna łatwość $\mathrm{w}$ pozyskiwaniu drewna w połączeniu $\mathrm{z}$ rozwijającym się przemysłem spowodowała, iż lasy znikły z powierzchni setek tysięcy kilometrów kwadratowych. Nie bez znaczenia był także rozwój kolei. Tysiące kilometrów torowisk wymagało milionów podkładów, produkowanych z drewna ${ }^{42}$. Dzięki odkryciom w chemii, skuteczniej impre-

\footnotetext{
${ }^{41}$ Trzeba przy tym dodać, że Europa jest jedynym kontynentem, na którym w ciagu ostatnich dekad wzrosła średnia lesistość i wynosi ok. 33\%. Także w Polsce powiększyła się powierzchnia lasów, z ok. $26 \%$ po drugiej wojnie światowej do $29 \%$ obecnie.

${ }^{42}$ „Wielkie połacie lasów - pisze James Burke - wycinano w pień bez mrugnięcia powieką (...). W połowie XIX wieku leśnictwo amerykańskie stało się pierwszym w historii przykładem destrukcyjnej i rabunkowej gospodarki na wielką skalę. Gdyby koleje na tym kontynencie miały się rozwijać w takim samym tempie przez następnych kilkadziesiąt lat, prawdopodobnie amerykańskie lasy przestałyby istnieć. Nic dziwnego, że stan Michigan ( $w$ którym podstawowym gatunkiem lasotwórczym była sosna amerykańska Pinus strobus L.) został do końca XIX wieku kompletnie ogołocony";
} 
gnowano drewniane podkłady, co zapobiegło całkowitej dewastacji obszarów leśnych ${ }^{43}$.

To samo można by powiedzieć o pozyskiwaniu kopalin. Rewolucja naukowa, oprócz wezwania do innowacyjności, przyniosła także desakralizację przyrody. W niepamięć odeszły alchemiczne wizje Ziemi jako rodzącej matki, a człowieka jako akuszera. Coraz większe i wydajniejsze maszyny parowe wymagały coraz większej ilości węgla i żelaza. Nie było już miejsca na modlitwy i tajemną wiedzę, za to wzrosło zapotrzebowanie na wiedzę $z$ geologii, metalurgii, ekonomii. To nie przypadek, że w szesnastym wieku ukazały się dzieła $\mathrm{z}$ tego zakresu - w 1540 roku Włoch Vannoccio Bringuccio wydał Pyrotechnię o hutnictwie, odlewnictwie i obróbce metali, a w 1556 Niemiec Georgikus Agricola napisał dzieło De re metallica, librii XII o kruszcach i górnictwie. I choć pobrzmiewała w nich alchemiczna nuta, dalekie już one były od treści prac Paracelsusa, a nawet Jana Babtisty van Helmonta. Warto zwrócić uwagę, że kiedy Franciszek Bacon nawoływał do gromadzenia danych (obserwacji, eksperymentów itd.) $z$ każdej dziedziny wiedzy ${ }^{44}$, postulat ów został już zrealizowany $\mathrm{w}$ wymienionych dziełach. Istniał już zatem pewien wzorzec. Dzieła te były czymś w rodzaju podręczników porządkujących, a przede wszystkim gromadzących szczegółową wiedzę; były to Baconowskie „historie naturalne”.

Ale desakralizacja połączona $\mathrm{z}$ wiedzą techniczną przyniosła podobny skutek, jak w rolnictwie - eksploatację na masową skalę i nieskrępowane przełamywanie każdych ograniczeń. Od tej pory ani wierzenia, ani praktyki magiczne, ani bariery geograficzne i techniczne nie mogły zapobiec wydobyciu kopalin. Technika umożliwiała pozyskiwanie niedostępnych dotąd pokładów, ale także otworzyła zapotrzebowanie na nowe surowce - już nie tylko drewno i weggiel, miedź i żelazo, ale gaz i ropa, rzadkie metale i minerały, stały się jej celem.

por. J. Burke, Skojarzenia. Fascynujace podróże po świecie odkryć i wynalazków, thum. M. Czekański, Wiedza i Życie, Warszawa 1999, s. 59-60. Nietrudno zgodzić się z tym drugim wnioskiem. Natomiast rabunkowe wycinanie lasów miało już miejsce w Europie, jednakże w Stanach Zjednoczonych przybrało to masową skalę i niespotykane dotąd tępo.

${ }^{43}$ Drewno wystawione na działanie deszczu i mrozu szybko ulegało zniszczeniu. Wymagało to wymiany podkładów, linii telegraficznych, elementów drewnianych mostów. Proces ten można było zahamować impregnując drewno, tak więc ,jeden z produktów ubocznych destylacji smoły uratował lasy w Ameryce: był to gęsty, oleisty, czarny płyn zwany kreozotem. Drewno nasączone tą substancją wytrzymywało na otwartej przestrzeni trzydzieści siedem lat zamiast siedmiu"; por. J. Burke, Skojarzenia..., dz. cyt., s. 61-62.

${ }^{44}$ F. Bacon, Novum..., dz. cyt., s. 10, 139, 174. 
Proces ten, przyczynił się do powstania czegoś, co nazywamy uprzemyslowieniem. Idea, aby pracę człowieka zastąpić pracą maszyn jest zupełnie czym innym, niż zastąpienie ludzi zwierzętami. Udomowienie koni i bydła (w Indiach słoni, a na północy reniferów itp.), które w pewnych warunkach mogły wykonać za człowieka jego pracę, przyczyniły się zapewne do podniesienia wydajności, ale siłą rzeczy zaangażowanie zwierząt było ograniczone do najprostszych działań w charakterze „napędu", lub inaczej, źródła siły. Idea maszyny zastępującej człowieka w pracy wykraczała poza te nieskomplikowane, choć wymagające wysiłku, czynności. Chodziło o ty, by maszyna wykonywała zadania wymagające nie tylko „sprawności manualnej”, ale także i te, które z różnych powodów były człowiekowi niedostępne. Sądzę, iż dobrą ilustracją dla takiej koncepcji były maszyny tkackie, za pomocą których można było wykonać najbardziej skomplikowane wzory. W tym przypadku mamy do czynienia z pierwszą próbą „oprogramowania” maszyn. W 1800 roku „Joseph Marie Jacquard zaprojektował nawet nowoczesną kontrolę maszyn za pomocą kart perforowanych" 45 , do pewnego więc stopnia, maszyna mogła kontrolować się sama. Wmontowanie programu sterującego pracą urządzenia technicznego czyniło z niego jakąś quasi inteligentną istotę, co spowodowało, że przejście od „człowieka-maszyny” według La Mettrie'go do „maszyny-człowieka” w sferze techniki stało się możliwe w przeciagu kilkudziesięciu lat.

Połączenie owej sprawności maszyny i wykorzystanie przyrody jako źródła energii stanowiło już krok naprzód w drodze do coraz pełniejszego uniezależnienia się od siły ludzkich mięśni. Wykorzystanie wody jako źródła energii i środka do jej przenoszenia (para wodna) uczyniło z niej, niezbędny element rewolucji przemysłowej. Wykorzystywana do tej pory głównie w rolnictwie, wymagała sieci irygacyjnych (jak w Egipcie czy w państwie Khmerów) lub „wodociagów” (jak w Rzymie czy państwie Inków). Tymczasem wykorzystanie wody jako źródła energii wymusiło nowe rozwiązania techniczne. Jak widzieliśmy, w dawnych cywilizacjach budownictwo hydrotechniczne było rozwinięte nie gorzej niż w Europie w szesnastym, a nawet siedemnastym wieku. To, co zaczęło różnić inwestycje w Europie od przedsięwzięć w dawnych imperiach, to ich skala i technologia robót. Kanały przestały być siecią wykopanych rowów, a stały się skomplikowanymi budowlami kamiennobetonowymi, ze stalowymi, ruchomymi urządzeniami, poruszanymi siłą uzyskaną $z$ energii wody.

\footnotetext{
45 J. Bronowski, Potega wyobraźni, thum. S. Amsterdamski, PIW, Warszawa 1988, s. 269.
} 
Uprzemysłowienie jest niewątpliwie wyjątkową cechą zachodniej cywilizacji. Żadna poprzednia cywilizacja nie była uprzemysłowiona w naszym rozumieniu, to znaczy żadna nie używała narzędzi i maszyn napędzanych parą, a później elektrycznością, choć stosowała narzędzia, nie produkowała na masową skalę, choć wytwarzała, nie preferowała zestandaryzowanych, jednorodnych dóbr, mimo że powielała uznane wzorce.

Jak już wielokrotnie podkreślano, początkowo cywilizacja europejska funkcjonowała w podobny sposób i „na podobnych zasadach” jak minione cywilizacje starożytne i nowożytne poza Europa. Ale w „,pewnym momencie" Europa przekroczyła próg, dzięki czemu zapewniła sobie trwanie i rozwój do dzisiaj: próg - głodu, degradacji środowiska, przeludnienia, wojen itp. Stało się to możliwe dzięki odkryciom geograficznym $^{46}$, nauce i technice, a przede wszystkim gotowości do zmian i mobilności. Europa dzięki temu zaanektowała dla siebie nowe tereny, nowe światy, przedłużając - dosłownie i w przenośni - własne pola, lasy i łowiska, otwierając dla siebie nowe tereny do eksploatacji kopalin i zasobów naturalnych. Stając w obliczu nowych, nieznanych i niezmierzonych przestrzeni, nie odgrodziła się murem jak Chiny czy morzem jak Japonia. Co więcej zaprzegnięto technikę, by uczynić łatwiejszymi podboje nowych krain. Jeśli przypomnimy sobie z jakich powodów Krzysztof Kolumb podjął się wyprawy na Zachód, to staje się oczywiste, że nie przyświecały mu religijne cele, ale gospodarcze. Odkrycie morskiej drogi do Indii miało uniezależnić handel od pośredników. Idea konkurencji i potrzeba niezależności - to decydowało o tak niezwykłych przedsięwzięciach.

Wykraczając poza niewielki obszar jakim była Europa, jej mieszkańcy otworzyli sobie wrota do niezmierzonych bogactw, ale także stworzyli nowe zagrożenia, które znacznie trudniej zdiagnozować niż te ujawniające się wraz ze znikającymi lasami, pustynnieniem pól czy przeludnie-

46 Być może starożytni Grecy szybciej doprowadziliby do destrukcji własne środowisko naturalne, gdyby nie kolonizowali wybrzeży Morza Śródziemnego, zapobiegając W ten sposób przeludnieniu oraz coraz większemu rozdrobnieniu gospodarstw; por. Słownik pisarzy antycznych, red. A. Świderkówna, Warszawa 1982, s. 234 i n. Podobnie Rzymianie - prowadząc kolonizację na obszarze całego Morza Śródziemnego i części Europy Zachodniej nie tylko zapobiegli przeludnieniu, ale stworzyli dla siebie nieograniczone źródło, z którego płynęły wszelkie zasoby naturalne i dobra. Starożytny Rzym przypomina pod tym względem nowożytną Europę i, generalnie, współczesną cywilizację zachodnią - podbite (skolonizowane) tereny miały służyć zaspokajaniu coraz większych potrzeb niewielkiej populacji. 
niem. Owe zagrożenia są tym bardziej ukryte, im bardziej ich skutki są rozłożone w czasie i przestrzeni.

\section{Dlaczego współczesna cywilizacja nadal funkcjonuje?}

Można by zapytać inaczej - dlaczego współczesna cywilizacja, popełniając wszystkie błędy jakie stały się udziałem minionych społeczeństw i w dodatku na nieporównywalnie większą skalę, do tej pory nie podzieliła ich losu?

Eksploatując coraz to nowe rejony, coraz to nowe zasoby środowiska, ale także - dzięki nowym technologiom - coraz trudniej dostępne pokłady ${ }^{47}$, współczesna cywilizacja „przesuwa” granice „wydajności”, „pojemności" eksploatowanego środowiska. Filozofia ta (lub jak kto woli metoda) przypomina trochę metodę upraw rolnych w starożytności i średniowieczu, wyjałowione pole odłogowano przez kilka lat, zajmując nowe miejsce do uprawy, najczęściej wskutek wykarczowania lasu. Opuszczona rola, rzeczywiście do pewnego stopnia regenerowała się (o ile nie uległa dalszej degradacji, na przykład, z powodu erozji), umożliwiając $\mathrm{w}$ następnych latach ponowną uprawę. Choć należy dodać, że zasobność tych pól stale i systematycznie malała. Eksploatując jakiś region (makroregion), dzisiaj czynimy podobnie. Po wyczerpaniu surowców zamykamy kopalnie, opuszczamy łowiska, opuszczamy zręby i przenosimy się gdzie indziej. I to „gdzie indziej” ma zasadnicze znaczenie. Nie musimy przenosić się do sąsiedniej wsi, województwa, landu - możemy przenieść się na inny kontynent, inne morze lub ocean. Tę taktykę umożliwiają współczesne przedsiębiorstwa (megaprzedsiębiorstwa, mega-koncerny itp.), których struktura jest tak skonstruowana, by funkcjonowały zgodnie $\mathrm{z}$ tą filozofią. Wyczerpywanie zasobów na jednym kontynencie nie przeszkadza, by rozpocząć lub kon-

${ }^{47}$ Dzisiaj takim przykładem jest gaz pozyskiwany z łupków, a także ropa naftowa przetwarzana z gruntów, tak jak w Kanadzie. Ten sposób „wydobycia” ropy prowadzi do całkowitej dewastacji terenu - na obszarze 1000 kilometrów kwadratowych wycina się las i, dosłownie, mielone są tysiące ton ziemi. W porównaniu z tym pompowanie ropy z podziemnych złóż w Arabii czy Kuwejcie jest naprawdę ekologiczne. Poza tym, eksploatujemy bardzo rzadkie i nieznane do niedawna pierwiastki, które „odgrywają kluczową rolę w zielonej gospodarce (...) itr, neodym, europ, terb i dysproz - są niezbędnymi elementami żarówek energooszczędnych, potężnych magnesów i innych urządzeń technicznych. Inne substancje - gal ind i tellur - stosowane są w cienkowarstwowych ogniwach fotowoltaicznych”; por. S. H. Ali, Cudowne metale, „Świat nauki" luty 2014, 2(270), s. 18. Pozyskiwanie tych rzadkich pierwiastków rodzi problemy także natury prawnej i politycznej. Obniżanie limitów ich wydobycia może służyć zawyżaniu cen i hamowaniu rozwoju technologii. 
tynuować pracę w innym miejscu Ziemi w ramach tego samego gospodarczego podmiotu. A zatem struktura współczesnej gospodarki surowcami jest „dopasowana” do struktury współczesnych mega-koncernów. To, co wcześniej było taktyką pojedynczego gospodarza, spółki, gminy czy państwa, stało się domeną ponadpaństwowych, globalnych przedsiębiorstw. (Notabene, jest to z kolei możliwe dzięki ponadkontynentalnej koordynacji działań, którą zapewni współczesna technologia, umożliwiająca sprawną komunikację i „nieograniczony” przepływ informacji w krótkim czasie).

W efekcie siegamy po niedostępne do tej pory zasoby lub odkrywamy nowe. To daje złudne poczucie, że surowce (i produkcja żywności) są niewyczerpalne, a przynajmniej, że daleko nam jeszcze do osiagnięcia punktu krytycznego. Niejednokrotnie już wyczerpywały się niektóre zasoby, a jednak udawało się odkrywać inne. Szczególnie dotyczy to surowców energetycznych. Cywilizacja człowieka zasadniczo jest energochłonna, ale od czasów rewolucji przemysłowej obserwujemy nieustanny wzrost zużycia energii, choć należy zwrócić uwagę, że z gwałtownym wzrostem mamy do czynienia w ciagu ostatnich stu lat ${ }^{48}$. Ale czy w związku z tym, w ostatnich dekadach, jakieś państwo upadło z powodu braku energii? Nie. Dlaczego? Otóż dlatego, że eksploatujemy nie tylko coraz to nowe pokłady, ale i zmieniamy źródła energii - przechodząc od drewna, torfu i wegla, przez gaz i ropę do ,atomu”, wody i wiatru. Ta, być może krótkotrwała, zdolność do ciagłego zaspokajania zapotrzebowania na energię sprzyja, czy wręcz prowokuje do ciagłego wzrostu ich zużycia. Oczywiście nawoływanie do oszczędności ma także swoje znaczenie. Idea ta, jakkolwiek ekonomicznie uwarunkowana, ma też, tak sądzę, wymiar niemalże etyczny - wzywa nas do poszanowania tego, co oferuje przyroda. W praktyce oznacza to również, że jest zapotrzebowanie na coraz bardziej oszczędne energetycznie maszyny i narzędzia przy coraz większej ich wydajności i efektywności. Owe poczucie nieograniczoności zasobów (nie tylko energetycznych) może wzmacniać świadomość, że do tej pory nie zostały, w jakiś spektakularny i powszechnie znany sposób, wyczerpane najbardziej eksploatowane zasoby $^{49}$. Choć zamyka się poszczególne kopalnie (nawet cały przemysł wę-

\footnotetext{
${ }^{48}$ Por. na przykład Ilustrowany Wielki Atlas Świata, wyd. 2., Buchmann, Warszawa 2008, s. 31.

49 Swiatowe zapasy rezerw zasobów paliw kopalnych nie są do końca rozpoznane i nawet oficjalne dane nie mogą być uważane za w pełni miarodajne. Zasobność tych rezerw wpływa na politykę energetyczną, a tym samym na energetyczne bezpieczeństwo każdego państwa, dlatego też są one częściowo tajne. Musiałaby zmienić się filozofia polityki między państwami preferująca bardziej współpracę i pomoc niż konkurencję
} 
glowy, jak w Wielkiej Brytanii) lub szyby czy wieże wiertnicze, to nadal wydobywa się węgiel w Polsce, ropę w Teksasie, Arabii, Rosji czy na Morzu Północnym. Nadal karczuje się lasy Amazonii, Konga czy Borneo $^{50}$, nadal łowi się na Morzu Bałtyckim, Północnym, Chińskim i na innych akwenach. Wydaje się, że powszechna świadomość tego, iż zasoby naturalne są ograniczone, zacznie w nas funkcjonować wtedy, kiedy niektóre $z$ nich wyczerpią się ostatecznie, i to w sposób nieodwracalny. Dorst często podkreśla, że eksploatujemy zasoby nieodnawialne i że traktujemy je tak, jakby takimi nie były. Tymczasem raz wydobyta i zużyta ropa czy węgiel nigdy już nie staną się dostępnymi nam kopalinami. Alchemiczna wiara w to, że Ziemia potrafi odrodzić częściowo wydobyte kopaliny została odrzucona nie tylko w świetle badań nad surowcami, ale także z przyczyn czysto metodologicznych i filozoficznych ${ }^{51}$. W efekcie, Europejczycy wyzbyli się tych wszystkich obaw, które hamowały poczynania starożytnych Greków i ich samych w średniowieczu - nic, poza fizycznymi ograniczeniami, nie stało już na przeszkodzie, by eksploatować zasoby i przekształcać krajobraz. Budowa mostu nad Bosforem ziściła się - jego projektanci nie brali pod uwage "gniewu bogów”, a „tylko" częste w tym rejonie trzęsienia Ziemi.

Mówiąc krótko, fakt, iż współczesna cywilizacja ma zasięg globalny to znaczy eksploatuje środowisko całej planety - pozwala na jej stabilniejsze funkcjonowanie niż dawnym imperiom ${ }^{52}$. Zapewnia jej nieporównywalnie większą odporność na lokalne (z naszej perspektywy) zakłócenia ekologiczne, a tym samym jej ,żywotność”. Zasobność całej

i zysk, by dane o zasobach stały się powszechnie dostępne i wiarygodne. Niemniej szacuje się, że zapasy ropy naftowej wyczerpią się za ok. 40 lat, gazów naturalnych za ok. 60, a węgla za ok. 200. Ale przy tym warto pamiętać, że w samej Polsce dysponujemy ogromnymi, nieeksploatowanymi jeszcze pokładami węgla brunatnego w okolicach Legnicy, Lubina i Ścinawy.

${ }^{50}$ Oczywiście nie oznacza to, że w niektórych rejonach świata lasy nie zostały całkowicie wykarczowane. Na Madagaskarze pierwotna tropikalna puszcza została wycięta, a skutki tego odczuwalne są po każdych deszczach - spływająca po wylesionych zboczach woda, zamienia się w śmiertelne lawiny błotne. Innym przykładem może być tu wyspa Hispaniola, której zachodnią część zajmuje Haiti, a wschodnią Dominikana. Teren Haiti został całkowicie wylesiony w przeciwieństwie do obszaru Dominikany. Katastrofalne lawiny błotne i erozja gleby regularnie nawiedzaja ten pierwszy kraj, potęgując jego problemy gospodarcze i społeczne. Pogłębia to i tak już niemałą biedę.

${ }^{51}$ Przez wieki intensywność wydobycia kopalin była hamowana alchemiczną wizją przyrody jako matki. Dlatego „po okresie intensywnej eksploatacji kopalniom pozwalano na odpoczynek. Kopalnia, macica Ziemi, potrzebowała czasu, by znowu stać się płodną"; M. Eliade, Kowale i alchemicy, tłum. A. Leder, Aletheia, Warszawa 2007, s. 46.

${ }^{52}$ Por. przyp. 46. 
Ziemi wyznacza granice eksploatacji, które $\mathrm{z}$ tego powodu wydają się być bardzo odległe, a to z kolei staje się źródłem owego złudnego poczucia braku jakichkolwiek długotrwałych i „ostatecznych” zagrożeń. Sądzę, iż bardziej wiarygodna byłaby dla współczesnego człowieka wizja końca cywilizacji spowodowanego upadkiem asteroidy lub najazdem kosmitów, niż wyczerpaniem się zasobów ropy ${ }^{53}$.

Rozwój technologiczny, dzięki któremu obecna cywilizacja, bez „większych zakłóceń” nadal funkcjonuje (i który umożliwia globalną gospodarke), generuje także złudne przeświadczenie, a mianowicie o nieograniczonym, nieustannym charakterze tego postępu. Ostatnie trzy wieki, a szczególnie minione, stulecie uzmysławiają nam, że tak naprawdę trudno wyobrazić sobie, czego możemy jeszcze dokonać w technice, jakich możemy dokonać odkryć, co skonstruować itd. Choć wizje niezwykłych wynalazków, urządzeń czy maszyn budowano już dawno (Roger Bacon, Leonardo da Vinci, Franciszek Bacon i inni), to z perspektywy naszych osiagnięć, wydają się one mało rewolucyjne. Tak więc, być może i nasze oczekiwania, za sto lat okażą się nie dość śmiałe. Istotne jest jednak to, że w trakcie tych ostatnich trzech stuleci, nie tylko oswoiliśmy się z myślą o zmianach, które będą nam towarzyszyć, o nowych, nieznanych nam urządzeniach, które będziemy konstruować, ale ważne także jest $i$ to, iż uczyniliśmy $z$ tego niemal warunek konieczny naszej egzystencji. Uzależniliśmy wręcz od owego technicznego postępu (w każdej dziedzinie naszej działalności) dalsze funkcjonowanie cywilizacji. Wygląda to tak, jakby każdy wynalazek, każde urządzenie, ale także i każda myśl, idea były tylko etapem przejściowym ku czemuś doskonalszemu, wydajniejszemu, ku czemuś, co wprowadzi nas w nowy świat i pozwoli żyć, gdy ten dzisiejszy obumrze - a to sprawia, że wydaje nam się, że obecne środowisko w którym żyjemy, traktujemy jako tymczasowe, wymagające naprawy i rekonstrukcji. Tak jak pierwotnie takie myślenie realizowało się w rolnictwie, tak teraz taka filozofia „urządza” nam wszystkie wymiary naszego życia - te fizyczne, przestrzenne oraz intelektualne i emocjonalne. Tworzymy zatem własny świat, już nie tylko dlatego, żeby poprawić naturę, ale dlatego, że nie potrafimy żyć w innym świecie. Jak pisze Dorst „oszałamiająca sprawność, jaką osiagnęliśmy w najrozmaitszych dziedzinach, skłoniła nas do stworzenia jakiegoś sztucznego świata, który z początku był złączony z przyrodą, ale

\footnotetext{
${ }^{53}$ Myślę, że jest to psychologicznie dobrze uzasadnione. Asteroidy już wielokrotnie spadały na Ziemię, unicestwiając choćby dinozaury, tymczasem zasoby ropy czy węgla jeszcze nie „miały okazji” się skończyć.
} 
wkrótce ją zastąpił i przeciwstawił się jej"54. Ale też w konsekwencji odseparował współczesnego człowieka od przyrody. Brak kontaktu z nią, tego bezpośredniego, „niewypreparowanego”, jak w trakcie odpoczynku „na łonie natury”, znieczulił na jej potrzeby. Zastapiliśmy kontakt z żywą przyrodą aparatami, gadżetami, posłusznymi mechanicznymi niewolnikami ${ }^{55}$.

Są oczywiście niezaprzeczalnie pozytywne skutki różnorodnego rozwoju techniki, także dla środowiska. Do jednych $z$ nich należy możliwość wytwarzania nowych, nieznanych w naturze materiałów. Wiele technicznych idei ulegało zapomnieniu $\mathrm{z}$ powodu braku odpowiednich surowców lub nie realizowano ich nie tylko z przyczyn teoretycznych, ale także i z praktycznych - nie było bowiem odpowiedniego tworzywa do ich wykonania. Nie dowiemy się, ile pomysłów zarzucano tylko dlatego, że autorzy doszli do wniosku, że nie da się ich „nigdy zrealizować".

Wymieniając odkrycia z fizyki, chemii, biologii, gleboznawstwa, fizjologii roślin i hodowli zwierząt, Dorst wskazuje na ich znaczenie w rozwoju naszej cywilizacji, ale zaraz uświadamia jakie kryją się za nimi konsekwencje i jak wzajemnie potrafią się ograniczać. Oto dzięki genetyce moglibyśmy hodować rośliny rosnące szybciej, ale to $z$ kolei wymaga większej ilości wody, której właśnie zaczyna brakować. Potrzebne są zatem nowe systemy irygacyjne, które wymagają dodatkowych nakładów zwiększających koszty uprawy, co może prowadzić do nieopłacalności produkcji tych nowych odmian. Nieustannie należy podkreślać, że nie funkcjonujemy $\mathrm{w}$ izolacji, postęp $\mathrm{w}$ jednej dyscyplinie nie oznacza postępu w innej, co więcej, każdy wynalazek, maszyna itp. natrafia na pewien „opór otoczenia”, należy je więc „dopasować” do otoczenia tak, aby z nim współgrały, a nie tylko przekształcały.

Tak więc postęp technologiczny, coraz bardziej wyrafinowane narzędzia i ich funkcje sprzyjają wizji o nieograniczonych możliwościach eksploracyjnych i eksploatacyjnych ${ }^{56}$. Możliwość wydobycia ropy z Arktyki

\footnotetext{
${ }^{54}$ J. Dorst, Siła.., dz. cyt., s. 129.

${ }^{55}$ Tamże. Jean Dorst Siłe życia pisał w latach siedemdziesiątych dwudziestego wieku, myślę, że czterdzieści lat później, byłby jeszcze bardziej zdumiony tym, jak dalece człowiek otoczył się owymi ,gadżetami” i uzależnił się od nich.

${ }^{56}$ Ale ten postęp technologiczny może być pozorny i bardzo mylący. Na przykład samochód - szczycimy się tym, jak bardzo zmienił się od swojego powstania. Tymczasem tak naprawdę nie zmienił się w ogóle w swej istocie. Co prawda zmienił się jego wygląd, dzięki nowym technologiom uległy rewolucyjnym przemianom materiały, z których jest zbudowany - stal, tworzywa sztuczne, zmieniło się oprzyrządowanie, dzięki tym wszystkim zmianom współczesny samochód jest nieporównywalnie
} 
„zawdzięczamy” nie tylko ociepleniu klimatu (łagodniejsze i krótsze zimy oznaczają cieńszą i mniejszą pokrywę lodowa), ale także właśnie dzięki nowym technologiom pozwalającym wytwarzać materiały odporne na mróz. Te nowe technologie umożliwiają odkrywanie nowych pokładów surowców - Ziemia jest duża, więc myśl o tym, że istnieją jeszcze nieznane nam olbrzymie złoża ropy, wegla wcale nie jest absurdalna. Co więcej, dzięki nim możemy „wyjść” poza Ziemię i eksploatować kosmos. Korzystanie z energii Słońca jest tego najlepszym przykładem taka „eksploatacja” wydaje się być ideałem, nie szkodzimy Słońcu, nie niszczymy Ziemi ${ }^{57}$. Ale i tu czai się często pomijany problem; otóż wytwarzanie baterii słonecznych, które są rzeczywiście „cudem techniki”, wiąże się z olbrzymimi nakładami energii. Do końca nie wiadomo, jaki jest ostateczny energetyczny bilans. A więc znowu to przyroda stawia nam ograniczenia, które musimy uwzględniać. Po raz kolejny uzmysławiamy sobie, że nasza cywilizacja nie może się rozwijać „w nieskończoność". Także Jean Dorst nie pozostawia w tej kwestii złudzeń - jak głosi tytuł jednego rozdziału Nasza cywilizacja też jest śmiertelna ${ }^{58}$ : współczesny świat nie jest raz na zawsze uodporniony na wszelkie zagrożenia, które sam generuje.

oszczędniejszy, wydajniejszy i bardziej „ekologiczny” niż pojazdy sprzed pięćdziesięciu i więcej lat. Nie zmieniło się "tylko" to, że nadal jest po prostu maszyną cieplną, zamieniającą energię cieplną na energię kinetyczną. I nie ma znaczenia, czy jako źródło energii służyć będzie drewno, ropa, gaz czy wodór. To paliwa mogą być coraz bardziej rewolucyjne, a nie samochód.

${ }^{57}$ Miałem okazję uczestniczyć w dyskusji na temat wykorzystania energii słonecznej. $\mathrm{W}$ jej trakcie jeden $\mathrm{z}$ uczestników stwierdził, że bateriami słonecznymi można byłoby pokryć Saharę i w ten sposób zapewnić czystą energię całej Europie. W odpowiedzi na tę z pozoru oczywistą ideę zwrócono uwagę, że mogłoby to zaburzyć globalną równowagę związaną $z$ nasłonecznieniem. Piaski Sahary pochłaniają i odbijają określoną ilość światła słonecznego (stosunek ten nazywamy albedem), co ma znaczenie dla naszego klimatu. Baterie słoneczne zmieniłyby tę relację.

W latach sześćdziesiątych pojawił się pomysł zawrócenia biegu rzek syberyjskich i skierowania części ich wód na pustynie Kazachstanu. Dopiero kiedy zaczęto mówić, że może to zakłócić tempo obrotu Ziemi wokół własnej osi, zaniechano realizacji tego projektu. W tym czasie jednak zabudowano rzeki Amu-darię i Syr-darię i zaczęto odprowadzać $\mathrm{z}$ nich wodę na tereny przyległe, które przekształcono w pola bawełny. W efekcie, w ciagu pięćdziesięciu lat, zasilane przez te rzeki Jezioro Aralskie zmniejszyło swoją powierzchnię o $75 \%$. W lokalnej skali oznaczało to prawdziwą katastrofe ekologiczną na miarę katastrof państwa Khmerów czy Majów. Jednak dla współczesnej, globalnej cywilizacji nie ma ona większego znaczenia - nie odczuli jej nie tylko Europejczycy, ale nawet mieszkańcy dalszych rejonów Kazachstanu czy Uzbekistanu. Wodę można przecież czerpać $\mathrm{z}$ głęboko położonych wód podziemnych, niedostępnych jeszcze sto lat temu.

${ }^{58}$ J. Dorst, Siła..., dz. cyt., s. 132. 
Rozwój techniki i technologii sprawia, że po raz kolejny przesuwamy granice „wydolności” eksploatacyjnej naszego środowiska przyrodniczego. Można rzec, że dzięki temu jesteśmy w podobnej sytuacji jak Europejczycy po odkryciu Ameryki ${ }^{59}$. Technologia sprawia, że przed nami odsłania się „nowy kontynent”, choć ściślej mówiąc, to my sami „konstruujemy" go dla siebie. Ale faktem jest, że eksploatując i eksplorując coraz to nowe rejony Ziemi i coraz to nowe zasoby, wykraczamy i sięgamy poza znany nam horyzont, tak jak Kolumb, Magellan i inni. Owo „zasiedlanie nowego kontynentu” nie jest tak spektakularne jak odkrycie Ameryki, ale pozwala współczesnej cywilizacji funkcjonować bez dramatycznych zwrotów. Na Ziemi, geograficznie, nie ma już możliwości odkrycia i zasiedlenia nowych kontynentów ${ }^{60}$, przy tak niskim nakładzie kosztów i tak obfitującym w bogactwa. Sądzę, że by sobie uzmysłowić, jakim szczęśliwym zrządzeniem losu dla Europejczyków były skutki wyprawy Kolumba, musielibyśmy sobie dziś wyobrazić, że odkryliśmy nową planetę, taką jak Ziemia, gotową do zasiedlenia i co więcej, w zasięgu naszych możliwości komunikacyjnych. Dzięki współczesnej wiedzy astronomicznej wiemy jednak, że ten wariant nieprędko się spełni.

Współczesna technika i technologia generują jeszcze jedno, niebezpieczne i fałszywe przekonanie. Otóż dzięki nim przepływ dóbr, zasobów, bogactw itd. jest praktycznie nieograniczony. Ich swobodna dystrybucja jest zbawienna dla wielu gospodarek i także dla wielu konsumentów. To, co było niedostępne z natury rzeczy, za sprawą rozwiniętej komunikacji i mobilności pojawia się w zasięgu ręki, a dzięki masowej skali tego procesu, nie jest przeznaczone tylko dla wybranych. Powód, dla którego Kolumb podjął się wyprawy „w nieznane” (używam tu cudzysłowu właśnie dlatego, że cel wyprawy był mu znany, nieznana była natomiast droga i ewentualne przeszkody) to ograniczona podaż cenionych przypraw. Ale powszechna dostępność do egzotycznych towarów (i usług) sprawiła, że straciliśmy poczucie ich naturalnej reglamentacji wiążącej się z występowaniem, wegetacją, potencjałem środowiska itd. Zboża, kawa, pomarańcze i inne płody rolne są uprawiane na całym świecie. Technologia natomiast umożliwia ich długotrwałe przechowy-

${ }^{59}$ Kolonizacja Ameryki Północnej jak w soczewce skupia wszystkie mechanizmy iskutki globalnej kolonizacji jakiej dokonują Europejczycy od wyprawy Kolumba. Najpierw jest to aneksja ziem, później podporządkowanie sobie ludności tubylczej, a następnie rabunkowa eksploatacja środowiska naturalnego.

${ }^{60}$ W futurystycznych wizjach takim „kontynentem” są dna oceanów lub Antarktyda - zielona i przyjazna, po stopnieniu lodowców. 
wanie, dzięki czemu są dostępne praktycznie w ciagu całego roku ${ }^{61}$. W latach nieurodzaju niedobór produktów możemy pokryć zapasami zmagazynowanymi z lat urodzaju ${ }^{62}$; innymi słowy, nieurodzaj w jednym miejscu skutkuje tym, że brakujące towary są sprowadzane $\mathrm{z}$ innych rejonów. Tym samym, klęska dla rolnika z Peru czy Tanzanii, praktycznie nie jest odczuwalna dla Europejczyka.

\section{Zakończenie, czyli pytanie o rolę filozofii w budowaniu nowej wizji świata}

Rozwój nauki i techniki sprawił, że mamy coraz lepszą znajomość, coraz głębszą wiedzę o zależnościach ekologicznych nie tylko w skali lokalnej, ale i globalnej. Jesteśmy świadomi oddziaływań w przyrodzie, o których jeszcze pięćdziesiąt lat temu uczeni nie mieli pojęcia. Któż wówczas spodziewałby się, że piaski Sahary, a szczególnie te znad Jeziora Czad, użyźniają gleby w dorzeczu ... Amazonki. Lasy nad tą rzeką są tak bogate dzięki procesom zachodzącym tysiące kilometrów dalej, na innym kontynencie. Nie wiedzieliśmy, że używane przez nas freony mogą zagrozić życiu na Ziemi, niszcząc powłokę ozonową, a zatruwając powietrze w Europie, wpływamy na stan środowiska na Antarktydzie. Te zależności można było odkryć dopiero, gdy udało się połączyć wyniki badań prowadzonych na całym świecie; ale przy tym należało zmienić wizję przyrody w skali globu, powrócić do idei biosfery głoszącej organiczną całość żywego systemu, wykluczającą możliwość funkcjonowania odizolowanych ekosystemów, odpornych na wszelkie zmiany zachodzą-

61 I znowu sięgnijmy do przykładu $\mathrm{z}$ terenu Stanów Zjednoczonych. „Współdziałające ze sobą kompanie kolejowe uruchomiły ponad czterdzieści szybkich linii tranzytowych, umożliwiając utrzymanie ciagłego strumienia dostaw, które trafiały wprost do miejsc przeznaczenia (...) Skonstruowano specjalne wagony do przewozu żywych zwierząt. Pierwsze $\mathrm{w}$ historii wagony-chłodnie przewoziły świeże truskawki z Illinois na Wschodnie Wybrzeże już w połowie lat siedemdziesiątych XIX wieku, a nowojorczycy mogli pić świeże mleko po raz pierwszy od dziesiątków lat"; por. J. Burke, Skojarzenia..., dz. cyt., s. 41.

${ }^{62}$ Przypomina to biblijną przypowieść o magazynowaniu zboża, w której czytamy, że „kiedy minęło siedem lat urodzaju w Egipcie, nadeszło siedem lat głodu, jak to zapowiedział Józef. A gdy nastał głód we wszystkich krajach, w całym Egipcie była żywność"; Biblia tysiaclecia, Rdz. 41,53-54, Poznań-Warszawa 1980. Współczesne najbogatsze państwa cywilizacji zachodniej są dla mnie egzemplifikacją owego biblijnego Egiptu. O ile jednak Egipt uchronił się od głodu dzięki snom faraona i ich natchnionej przez Boga interpretacji Józefa, to obecnie dostęp do nagromadzonych zasobów żywności wynika tylko z możliwości dystrybucji, zależnej od siły pieniądza i technologii. 
ce w otoczeniu ${ }^{63}$. Nauczyliśmy się także, że owe zależności wcale nie są ani proste, ani jednoznaczne, ani łatwo przewidywalne. Tym bardziej, że współczesna cywilizacja przypomina wielki eksperyment - sposób w jaki funkcjonujemy obecnie jest bezprecedensowy i nie wiemy jakie będą skutki tego „eksperymentu”. Możemy tylko budować pewne analogie, ale są one o tyle słuszne, o ile dotyczą tylko bezpośrednich skutków dla środowiska.

Znajomość tych zależności każe nam, a niejako wymusza na nas i na naszych działaniach, dbałość o przyrodę. Ale czy wówczas stoi za tym troska o jej dobro, czy tylko strach przed niebezpiecznymi dla nas samych konsekwencjami? Zdajemy sobie sprawę $\mathrm{z}$ tego, iż przyroda istniała i nadal może istnieć bez nas; że wbrew naszym mniemaniom o nas samych jesteśmy tylko kolejnym gatunkiem zasiedlającym Ziemię, gatunkiem, który miał swój ewolucyjny początek i zapewne będzie miał swój ewolucyjny, biologiczny kres i co więcej, w geologicznej skali czasu, cokolwiek byśmy zrobili i tak nie będzie to miało większego znaczenia dla życia na Ziemi.

Dorst przyznaje, że w dwudziestym wieku pojawiło się nowe spojrzenie na przyrodę i że twórcami owych idei byli tacy uczeni i filozofowie, jak T. Monod, J. B. Cobb, T. Sieger Derr, A. Schaeffer, P. T. de Chardin i inni ${ }^{64}$. Myśliciele ci „spróbowali zestawić wnioski, do jakich doszła nauka, ze wskazaniami religii. Przedmiotem swej refleksji uczynili stosunek ekologii do teologii" ${ }^{65}$. Dorst wskazuje na wspólny mianownik tych i im podobnych dzieł - otóż autorzy ci uzmysławiają nam, że nauka i technika nie rozwiążą wszystkich problemów gospodarczych i ekologicznych, bowiem wiele $\mathrm{z}$ nich ma swoje źródło w innym „wymiarze”, w moralności, w duchowości człowieka, w jego religijności; i - dodam $\mathrm{w}$ filozoficznych ideach, zgodnie $\mathrm{z}$ którymi on postępuje i postrzega świat.

W ciagu czterdziestu lat, które minęly od powstania książki Siła życia nikt nie wątpi w to, że człowiek musi zmienić swój stosunek i swoje myślenie o przyrodzie, choć $\mathrm{z}$ drugiej strony, nadal jesteśmy świadkami ludzkiego działania niszczącego środowisko w imię zysków i polepsze-

${ }^{63}$ Zapewne to zainspirowało powrót do idei Gai. W latach siedemdziesiątych James Lovelock napisał książkę zatytułowaną Gaja. Nowe spojrzenie na życie na Ziemi, tłum. M. Ryszkiewicz, Prószyński i S-ka, Warszawa 2003; a więc wtedy, gdy z całą ostrością zaczęliśmy zdawać sobie sprawę $\mathrm{z}$ rozmiarów negatywnych dla przyrody skutków naszej działalności. Z drugiej strony warto też dodać, że trzydzieści lat później, trochę z przekory, Peter Ward napisal Hipotezę Medei.

${ }^{64}$ J. Dorst, Sita.., dz. cyt., s. 81-84.

${ }^{65}$ Tamże, s. 81. 
nia własnej egzystencji. Co roku wycinamy miliony hektarów lasów tropikalnych i tajgi ${ }^{66}$, niszczymy ziemię wydobywając najprostszymi, najtańszymi metodami diamenty i złoto, zwiększamy kwoty połowów ryb, do „celów naukowych” łowi się wieloryby itd.

Praktycznie, w ciagu ostatnich czterdziestu lat powstała bioetyka, ale czy zmieniło to los hodowanych na masową skalę zwierząt lub tych trzymanych w naszych domach? Czy dyscyplina ta nie jest tylko idea filozoficzną, która nie odgrywała i nie będzie odgrywać żadnej poważniejszej roli w relacji człowieka ze zwierzętami? Czy w związku z tym, możliwe jest, byśmy kiedyś zaczęli traktować otaczającą nas przyrodę tak, jak indiański wódz Seattle, który w liście do prezydenta Stanów Zjednoczonych w 1855 roku (prezydentem był wówczas Franklin Pier$\left(\mathrm{ce}^{67}\right.$ ) pisał: „A więc wielki biały wódz z Waszyngtonu mówi, że chce kupić naszą ziemię. Jak można kupić lub sprzedać niebo? Ciepło ziemi? (...) Nie jesteśmy właścicielami świeżości powietrza ani blasku wody. Jak więc możecie je od nas kupić? Każda cząstka tej ziemi jest dla mojego ludu święta. (...) Czerwony człowiek ceni powietrze, bo wszystko oddycha tym samym: zwierzę, drzewa, człowiek. Biały człowiek zdaje się nie zauważać powietrza, którym oddycha (...) traktujcie zwierzęta tego kraju jak swoich braci. Bo gdyby wszystko znikło, człowiek umarłby od wielkiej samotności”68. Dorst zapewne podpisałby się pod tym wezwaniem...

Bez zmiany naszego (globalnego) nastawienia do przyrody, takie jej pojmowanie będzie charakterystyczne tylko dla garstki ludzi, budząc u pozostałych uśmiech. Ale czy ta zmiana jest możliwa w świetle biblij-

\footnotetext{
${ }^{66} \mathrm{Na}$ przykład, każdego roku w Afryce wycinanych jest $5 \mathrm{mln}$ ha (50 tys. $\mathrm{km} \mathrm{kw}$.) lasów; w Amazonii wycinanych jest ok. $2 \mathrm{mln}$ ha (20 tys. $\mathrm{km} \mathrm{kw.),} \mathrm{a} \mathrm{nowy} \mathrm{plan}$ zagospodarowania tych terenów przyjęty przez rząd Brazylii spowoduje wycięcie od $30 \%$ do $40 \%$ pozostałego obszaru w ciagu kilku najbliższych lat. Powyższe dane podaję za: Wielki atlas świata, dz. cyt. Z tym samym zjawiskiem mamy do czynienia w Azji południowo-wschodniej. Filipiny pierwotnie las pokrywał w $96 \%$, obecnie jest to mniej niż 18\%, z czego tylko 7\% to pierwotna puszcza; por. P. J. Vesilind, T. Laman (zdjęcia), Filipiny, zielony tygiel, „National Geographic. Polska” 2002, 7(34), s. 9. Także, praktycznie całkowicie, została wylesiona Jawa. W tym miejscu należy wspomnieć także i o innym zjawisku. Otóż w strefie tropikalnej funkcjonują ekosystemy, które nazywa się „zielonymi pustyniami”. Sa to rozległe plantacje palm i innych drzew, w których występuje niewielka, w porównaniu $\mathrm{z}$ naturalnymi na tym terenie ekosystemami, różnorodność ptaków, owadów, płazów itp.

${ }^{67}$ Franklin Pierce (1804-1869) funkcję prezydenta Stanów Zjednoczonych pełnił w latach 1853-1857.

${ }^{68}$ J. Dorst, Siła..., dz. cyt., s. 200.
} 
nej wizji człowieka i jego związków ze środowiskiem polegających na „Czynieniu sobie Ziemi poddaną”?

W niniejszej pracy starałem się wykazać, podazżając przy tym śladami Jeana Dorsta, że każde działanie prowadzone nawet $\mathrm{w}$ imię idei postępu, które narusza istniejącą $\mathrm{w}$ przyrodzie równowagę $\mathrm{i}$ wymaga nieustannego, coraz większego jej eksploatowania, prowadzi do nieodwracalnych, niekorzystnych dla nas samych zmian. W tym sensie pojmuję sformułowanie zawarte $\mathrm{w}$ tytułowym pytaniu, że owa destrukcyjność tkwi immanentnie w naszej aktywności. Przyroda bowiem stawia nam ograniczenia i jeżeli nie będziemy liczyć się z nimi, to wygenerujemy problemy, których nie będziemy w stanie później rozwiązać. Sądzę, że przytoczone przykłady dobrze ilustrują powszechność i skalę zagrożeń, $z$ jakimi człowiek miał i nadal ma do czynienia. $Z$ drugiej jednak strony, choć owa destrukcyjność w pewnym sensie towarzyszy każdemu działaniu, to nie jest ona czynnikiem bezwzględnie prowadzącym do zagłady przyrody i nas samych jako jej wytworu. Efekty naszej aktywności można łagodzić i neutralizować. Wymagałoby to jednak zmiany tkwiącej w nas filozofii wobec przyrody, co zapewne będzie się wiązało ze wzrostem kosztów i nakładów. Tak więc kwestią priorytetów jest wybór pewnej filozofii wizji celów i sposobów ich realizacji, także wybór tych lub innych fundamentalnych opcji, na które łożyć będziemy środki i w związku z którymi będziemy formułować swoje idee.

\section{Bibliografia}

Ali S. H., Cudowne metale, „Świat nauki” 2014, 2(270).

Bacon F., Novum Organum, thum. J. Wikarjak, PWN, Warszawa 1955.

Biblia tysiaclecia, Rdz. 41,53-54, Poznań-Warszawa 1980.

Bronowski J., Potega wyobraźni, thum. S. Amsterdamski, PIW, Warszawa 1988.

Bryson R. A., Climate modification by air pollution, [w:] The Enviromental Future, red. N. Polunin, Macmillan, London 1972

Burke J., Skojarzenia, Fascynujace podróże po świecie odkryć i wynalazków, tłum. M. Czekański, Wiedza i Życie, Warszawa 1999.

Cary M., Scullard H. H., Dzieje Rzymu, tłum. J. Schwakopf, PIW, Warszawa 1992.

Crick F., Istota i pochodzenie życia, tłum. A. Hoffman, PIW, Warszawa 1992. 
Crombie A. C., Nauka średniowieczna i poczqtki nauki nowożytnej, thum. S. Łypacewicz, t.1, PAX, Warszawa 1960.

Dorst J., Sita życia, tłum. W. Dłuski, PIW, Warszawa 1987.

Eliade M., Kowale $i$ alchemicy, thum. A. Leder, Aletheia, Warszawa 2007.

Ferguson N., Cywilizacja. Zachód i reszta świata, tłum. P. Szymor, Wydawnictwo Literackie, Kraków 2013.

Gray J., Stomiane psy. Myśli o ludziach i innych zwierzętach, thum. C. Cieśliński, Warszawa 2003.

Greenblatt S., Zwrot. Jak zaczat sie Renesans, tłum. M. Słysz, Wydawnictwo Albatros A. Kuryłowicz, Warszawa 2012.

Hezjod, Narodziny bogów (Theogonia) Prace i dni. Tarcza, thum. J. Łanowski, Prószyński i S-ka, Warszawa 1999.

Husserl E., Kryzys nauk europejskich i fenomenologia transcendentalna, tłum. S. Walczewska, Wydawnictwo Rolewski, Torun 1999.

Ilustrowany Wielki Atlas Świata, wyd. 2., Buchmann, Warszawa 2008.

Kolumella L. I. M., O rolnictwie, thum. I. Mikołajczyk, Ossolineum, Wrocław-Warszawa-Kraków 1991.

Kossobudzka M., Ryżowy wschód kontra pszeniczny zachód, Gazeta Wyborcza, piątek 16 maja 2014, s. 24-25.

Kuhn T., Tradycje matematyczne a tradycje eksperymentalne $w$ rozwoju nauk fizycznych, [w:] Dwa bieguny: tradycja $i$ nowatorstwo $w$ badaniach naukowych, tłum. S. Amsterdamski, PIW, Warszawa 1985.

Kunicki-Goldfinger W. J. H., Znikad donikad, wyd. 2., PIW, Warszawa 1993.

Lorenz K., Regres czlowieczeństwa, thum. A. D. Tauszyńska, PIW, Warszawa 1986.

Lovelock J., Gaja. Nowe spojrzenie na życie na Ziemi, thum. M. Ryszkiewicz, Prószyński i S-ka, Warszawa 2003.

Stownik tacińsko-polski, red. M. Plezia, PWN, Warszawa 1998.

Stownik pisarzy antycznych, red. A. Świderkówna, Wiedza Powszechna, Warszawa 1982.

Vesilind P. J., Laman T. (zdjęcia), Filipiny, zielony tygiel, „National Geographic. Polska" 2002, 7(34), s. 9.

Ward P., Hipoteza Medei. Czy życie zmierza do samounicestwienia?, thum. M. Betley, Prószyński i S-ka, Warszawa 2010.

Warron M. T., O gospodarstwie rolnym, thum. I. Mikołajczyk, wyd. Ossolineum, Wrocław-Warszawa-Kraków 1991.

Winniczuk L., Ludzie - Zwyczaje i obyczaje - Starożytnej Grecji i Rzymu, wyd. 2., PWN, Warszawa 1983. 


\section{Summary}

\section{The Human Being and the Environment - Is There Always a Seed of Destruction in the Idea of Progress? On the Ninetieth Anniversary of Jean Dorst's Birth (1924-2001)}

The key idea of Jean Dorst is the belief that the activity of all civilisations, as their technological and demographic development progresses, sooner or later leads to an excessive exploitation of the natural world. The consequence is that its resources deplete and state institutions collapse. Jean Dorst postulates the necessity to balance the needs of human beings and the capabilities of the environment, pointing to the role of science, politics, and even philosophy in solving these problems. Fifteen years after his death, his prognoses can be confronted with the actual development of civilisation and its impact on the environment, and the question „Must progress always be accompanied with destruction?" can be posed.

Keywords: civilisation/culture, progress, environmental threats, global civilisation

\section{Zusammenfassung}

Der Mensch und die Umwelt oder steckt in der Idee der Krise immer ein Kern der Destruktion? Anlässlich des 90. Geburtstags von Jean Dorst (1924-2001)

Der Hauptgedanke von Jean Dorst äußert sich in der Überzeugung, dass das Wirken aller Zivilisationen im Laufe ihres technischen Fortschritts und demographischen Entwicklung früher oder später zu einer übermäßigen Ausbeutung der umgebenden Natur führt. Folgerichtig bringt das die Verarmung ihrer Ressourcen und den Untergang der Staatsorganismen mit sich. Jean Dorst postuliert die Notwendigkeit des Gleichgewichts zwischen den Bedürfnissen der Menschen und den Möglichkeiten der Umwelt, wobei er auf die Rolle der Wissenschaft, der Politik und sogar der Philosophie bei Lösung der Probleme hinweist. 15 Jahre nach dem Tod des Gelehrten kann man seine Prognosen mit der tatsächlichen Entwicklung der Zivilisation und ihrem Einfluss auf die Umwelt konfrontieren. Und die Frage stellen: muss den Fortschritt immer die Zerstörung begleiten?

Schlüsselworte: Zivilisation/Kultur, Fortschritt, ökologische Bedrohungen, globale Zivilisation 
Pobrane z czasopisma http://kulturaiwartosci.journals.umcs.pl

Data: 26/04/2023 04:21:24

Zbigniew Pietrzak, Człowiek a środowisko...

Note about Author:

ZBIGNIEW PIETRZAK, Ph.D. in philosophy, assistant in the Department of Ontology and Theory of Cognition in Faculty of Philosophy, University in Wrockaw, Poland; address for correspondence: ul. Koszarowa 3/20, PL 51-149 Wrocław. E-Mail: zbigpietrzak@wp.pl 